\title{
FIDUCIARY ISSUES IN FEDERAL BANKING REGULATION
}

\author{
LAWRENCE G. BAXTER*
}

\section{I \\ INTRODUCTION}

John Seldon's "roguish" bête noire is still at it-this time in the unlikely domain of federal banking regulation. One of Equity's favorite doctrines, fiduciary obligation, has suddenly become important in the controversial realm of banking enforcement. When Congress substantially strengthened the enforcement powers of the banking agencies in 1989, it instructed the agencies "to aggressively utilize this new authority." ${ }^{2}$ The banking agencies ${ }^{3}$ have since filed hundreds of civil suits and agency enforcement actions against the officers and directors of banking ${ }^{4}$ institutions and against third parties, such as accountants, lawyers, and appraisers, who provided professional services to these institutions. Soon after the initiation of this new era of tough enforcement, the federal regulators began to espouse a very contentious version of the fiduciary duty doctrine as one of the grounds for implementing their new enforcement powers. They have argued that federally insured depository institutions, their officers and directors, and persons who contract with them, are under a direct fiduciary duty to act in the interests of the federal regulators.

The consequences of this combination of agency superpowers and enterprising equitable theory have not wanted for media headlines. The much-publicized action by the Office of Thrift Supervision ("OTS") against the New York law

Copyright $(\odot 1993$ by Law and Contemporary Problems

* Professor of Law, Duke University.

Paper presented to the Law and Contemporary Problems Symposium on Modern Equity, March $27 \& 28,1992$, and updated to April 10, 1992.

The author wishes to thank Keith R. Fisher, Dennis J. Lehr, Arthur W. Leibold, Jr., Andrew J. Nussbaum, Susan P. Strommer, and Peter P. Swire for their helpful comments, advice, and suggestions. The author is solely responsible for all the views expressed and for any errors.

1. John Seldon, Table TAlK 43 (Pollock ed. 1927):

Equity is a roguish thing. For law we have a measure .... Equity is according to the conscience of him that is Chancellor, and as that is longer or narrower so is equity. 'Tis all one as if they should make the standard for the measure a Chancellor's foot.

(translated from Old English by author). On the turbulent disputes between common lawyers and parliamentarians such as Coke, Seldon, and royalists such as Lord Chancellor Ellesmere and Attorney General Francis Bacon, see, e.g., JoHn H. BAKER, THE Legal PROFEsSion AND THE COMMON LAw ch. 13 (1986); L.A. KNAFLA, LAW AND POLITICS IN JACOBEAN ENGLAND ch. VI (1977).

2. CONFERENCE REPORT TO ACCOMPANY H.R. 1278, FINANCIAL INSTITUTIONS REFORM, RECOVERY AND ENFORCEMENT ACT OF 1989, H.R. REP. No. 101-222, 101st Cong., 1st Sess. 440 (1989).

3. For a description of the bank-regulatory structure, see note 11 infra.

4. "Banking" will be used in a broad sense throughout this article to refer to both commercial banks and savings and loan associations (thrifts), which together comprise the majority of depository institutions in the United States. 
firm of Kaye, Scholer, Fierman, Hays and Handler is the most dramatic example. ${ }^{5}$ The incident helped to highlight both the scale of the agency powers and the accompanying controversy over whether depository institutions and their affiliates owe a direct, general fiduciary duty to the federal banking agencies as guardians of federal deposit insurance funds. ${ }^{6}$

This article aims to disentangle the real fiduciary issues involved in this controversy from those of an independent statutory nature, and to demonstrate that the regulators' claim to the benefit of a fiduciary duty is not only unnecessary for protecting the public interest but is also legally incorrect. This article argues that the "fiduciary" duty being claimed by the regulators against depository institutions and their affiliates is actually a distinct statutory duty that is long standing, reasonably well understood by the parties involved, and already imposed on banks and those who do business with them, including their lawyers. This statutory duty is the duty not to engage in "unsafe and unsound" conduct, in other words, conduct that endangers the solvency of the institution. ${ }^{7}$ Though flexible itself, the safety/soundness standard is subject to many clearer prior rules and principles than is the vague notion of "fiduciary duty." By attaching an additional, "fiduciary" label to the statutory/soundness duty, the regulators have-whether intentionally or unintentionally-created an in terrorem effect, causing unneccesary debate and acrimony between the legal profession and the regulators. Clear statutory authority already exists for protecting the insurance

5. On March 2, 1992, the OTS filed administrative charges against three partners of that firm, seeking restitution of $\$ 275$ million for losses alleged to have been caused by the lawyers' improper representation of the infamous Lincoln Savings \& Loan Association. The complaint also sought orders prohibiting the three partners from representing banks, thrifts, and credit unions in the future. In addition, the agency imposed a freeze on the law firm's assets in anticipation of the adjudication of the charges against the three partners. See Stephen Labaton, U.S. Moves to Freeze Assets of Law Firm for S.\&L. Role, N.Y. TIMEs, Mar. 3, 1992, at A1; Paulette Thomas, Kaye Scholer Faces Civil Liability Suit for Losses at Lincoln; Assets Are Frozen, WALL ST. J., Mar. 3, 1992, at A3. The dispute has now been settled. See, e.g., Stephen Labaton, Law Firm Will Pay a \$41 Million Fine in Savings Lawsuit, N.Y. TIMES, Mar. 9, 1992, at A1; Sharon Walsh, Law Firm Settles S\&L Complaint, WASH. POST, Mar. 9, 1992, at A1; OTS, Kaye Scholer Agree to Settle; Firm Will Pay \$41 Million Restitution, 58 BNA BANKING REP. 472 (1993).

This is by no means the first such administrative action by the OTS (or other bank regulators) against law firms, but it is by far the largest to date.

6. Federally insured commercial banks are required to pay premiums into the Bank Insurance Fund ("BIF"), and their thrift counterparts pay into the Savings Association Insurance Fund ("SAIF"). Both funds are managed by the Federal Deposit Insurance Corporation ("FDIC"), a federal agency that has corresponding supervisory powers with respect to all federally insured banks and thrifts, but most banks and thrifts are subject to primary regulation by another federal regulator. See infra note 11.

These concerns also come at a time when, amidst the wreckage of leveraged buyouts gone wrong, there is renewed focus on the possibility of a similar fiduciary duty being owed by managers of corporations to their creditors instead of their stockholders. See infra text accompanying notes 79-81. Indeed, the controversy concerning the fiduciary duty of banks has already been caught up in this wider debate: Professor Coffee, one of the participants in the wider debate, specifically uses the example of failed banks and thrifts to advance his argument in favor of a general fiduciary duty to creditors. See John C. Coffee, Jr., Court Has a New Idea on Director's Duty, NAT'L L.J., Mar. 2, 1992, at 18.

7. See also Andrew J. Nussbaum, Like Money in the Bank? An Economic Analysis of Fiduciary Duties to Protect the S\&L Deposit Insurance Fund, 44 ADMIN. L. REV. 355 (1992) (reaching a similar conclusion with a somewhat different method of analysis, using portfolio theory to demonstrate why a general fiduciary duty would be economically inefficient and, ultimately, stultifying). 
funds and the public, and no statutory authority exists for the general fiduciary duty.

It is important to resolve this debate in the banking context for a number of reasons. First, a broad and general fiduciary duty owed directly to the federal regulators, were it to exist, would tend to impose upon banking institutions a duty of allegiance to the federal banking regulators that, given the vicissitudes of the political environment in which those regulators must operate, would be inherently vague and open-ended. Application of such a duty would require bankers to make their business decisions under the "brooding omnipresence" of severe regulatory sanctions, to which they would always be exposed if their decisions turned out to be bad. Characterizing decisions that subsequently turn out to be wrong as "breaches of a fiduciary duty to the federal regulator" would have the effect of enhancing both the administrative and the civil liability of bank managers. They would lose much of the benefit of traditional judicial deference to their discretionary business judgments; ${ }^{8}$ their decisions would be recast as involving matters of conscience and equity-the rectitude of which is primarily determinable by courts and, more importantly, regulators. ${ }^{9}$

Secondly, the existence of a general fiduciary duty owed directly to the federal regulators would have the effect of enhancing the importance of federal law and agency discretion in the domain of banking regulation. The general fiduciary duty would derive from the relationship between the federal insurer and the banks. Its content would have to be determined on a case-by-case basis by those regulators, to which the courts would be obliged to accord heavy deference.

Finally, the presence of such a duty would have the effect of enlarging the scope of outside counsel's potential liability. Attorneys providing legal services to banking institutions fall directly within the extensive enforcement jurisdiction of the regulators. They would have to become primarily concerned with their clients' direct fiduciary duties to the regulators. Outside counsel would, therefore, no longer be able to accept at face value the business judgments of their clients; instead, they would themselves have to act in anticipation of the often highly discretionary and mercurial views and after-the-fact censure of the regulators. Outside counsel are traditionally protected by the extent of disclosure given them by their clients; where they also owe a duty to a third party, such as the government, much greater self-protective and prophylactic measures would become necessary.

Part II of this article provides a brief overview of the enforcement powers now possessed by the banking agencies. Part III examines the statutory conditions under which breaches of fiduciary duty may give rise to enforcement action. It will be seen that the relevant statutory language is imprecise, providing some

8. See, e.g., Amerifirst Bank v. Bomar, 757 F. Supp. 1365, 1376 (S.D. Fla. 1991).

9. The agencies are able to enforce compliance with their predetermined standards of banking conduct by using their own enforcement powers, which the courts review according to highly deferential principles. 
scope for debate as to whether institutions and individuals might be subject to enforcement action when they act in a manner contrary to that desired by the regulators. Part IV then addresses the regulators' argument that they are the beneficiaries of a general fiduciary duty, securing for them the primary allegiance of depository institutions and persons involved with banking. The conclusion reached in Part IV is that, even though such a fiduciary duty might, in the absence of legislation, have arisen by virtue of the federal insurance protection provided to banking institutions, the protection this duty would have accorded has already been provided for by Congress in the statutory enforcement framework it has crafted over the years. Part V considers some of the implications the regulators' claim to a general fiduciary duty would have for one important group of professionals involved, namely, attorneys. The view adopted in Part V is that the manner in which Congress addressed the problem of attorney liability in connection with agency enforcement action provides further indications that it never intended to authorize the regulators to enforce a general fiduciary duty in their favor. The article concludes, in Part VI, with the view that the fiduciary duty doctrine cannot and should not be resorted to as a short-cut substitute for less convenient, yet more appropriate, legal analysis.

II

The Enforcement Powers of THe Federal Banking Agencies ${ }^{10}$

The enforcement powers now at the disposal of the federal banking agencies $^{11}$ are remarkably extensive; they comprise a complex mixture of statutorily created, "common law" and "equitable" remedies and sanctions. The combination, however, heavily disguises their genealogy.

10. This section does not address, directly, the historical development of banking enforcement powers. That development, however, is important for understanding the relationship of fiduciary duties to enforcement action, and it will be developed further infra text accompanying notes 104-21.

11. The principal banking regulators are the following: the Board of Governors of the Federal Reserve ("Fed"), which has primary federal responsibility for regulating all bank holding companies ("BHCs") and state-chartered banks who are members of the Federal Reserve System; the Office of the Comptroller of the Currency ("OCC"), a bureau in the Department of the Treasury, headed by the Comptroller of the Currency, with primary responsibility for regulating all national (federally chartered) banks; the Office of Thrift Supervision ("OTS"), also a bureau in the Treasury Department, headed by a Director, with primary responsibility for regulating all savings and loan holding companies and all federally-chartered savings associations (thrifts) and primary federal responsibility for regulating all statechartered, federally insured thrifts; and the Federal Deposit Insurance Corporation ("FDIC"), an independent federal agency with primary responsibility for regulating all state-chartered, nonmember, federally insured banks. As the federal insurer, the FDIC administers the two federal insurance funds for banks and thrifts, and it also has secondary regulatory authority over all federally insured banks and thrifts for which it is not the primary regulator. See infra the definition of "appropriate Federal banking agency" in 12 U.S.C. $\$ 1813(q)$ (1988), Statutory Appendix.

The FDIC is also appointed receiver for all failed national banks and most state-chartered banks. Insolvent thrift associations are being disposed of by the Resolution Trust Corporation ("RTC") for a limited time before the FDIC becomes the exclusive receiver of failed institutions.

The other segment of the depository institution industry, credit unionis; is regulated (and insured) fairly autonomously by the National Credit Union Administration. Credit unions are not addressed directly in this article. 
Until the mid-1960s, the federal enforcement powers comprised mainly "life and death" sanctions, including seizure of an institution for conservatorship or receivership, ${ }^{12}$ revocation of a banking charter, ${ }^{13}$ expulsion from Federal Reserve membership ${ }^{14}$ and termination of federal deposit insurance. ${ }^{15}$ The very severity of these sanctions tended to diminish their use, and informal coercion through the examination and supervision process constituted the principal mechanism for keeping depository institutions within regulatory bounds. ${ }^{16}$ During the past four decades, however, the regulators found they needed more differentiated and finely tuned remedies. Congress responded by providing the regulators with a formidable array of weapons. ${ }^{17}$ In addition to the powers already described (and a fresh bevy of bold, prompt corrective action powers to be used in the case of ailing institutions that are not yet insolven ${ }^{18}$ ), the regulators are now able to draw on a range of effective intermediate enforcement weapons. These weapons are effective whenever circumstances

12. See, e.g., 12 U.S.C.A. \$ 191 (West Supp. 1992) (national banks) (effective Dec. 19, 1992); 12 U.S.C. $\$ 192$ (1988); 12 U.S.C. $\$ 1821$ (c) (Supp. II 1990); 12 U.S.C.A. $\S 1821$ (c)(6)(B) (West Supp. 1992).

13. See, e.g., id. § 93 (1988 \& Supp. II 1990) (national banks).

14. See id. $\$ 327$ (1988). Cf. id. \&1426(e) (Supp. II 1990) (termination of thrift membership in Federal Home Loan Bank system).

15. See 12 U.S.C. \& 1818(a)(2) (Supp. II 1988). Under the Banking Act of 1933, \& 30, 12 U.S.C. \& 77 (repealed in 1966), the Fed also had limited power to remove officers of member banks. See, e.g., Board of Governors of the Federal Reserve System v. Agnew, 329 U.S. 441 (1947). Under the Housing Act of 1954, the Federal Home Loan Bank Board could issue orders to enforce compliance with law and regulations, but the applicability of the law could be taken directly to a federal district court for trial de novo. 12 U.S.C. \& 1464(d)(1) (repealed in 1966). For subsequent statutory reforms, see infra text accompanying notes $107-21$.

16. Informal supervision, backed by extremely severe sanctions, could, of course, achieve substantial results. See, e.g., Miami Beach Fed. Sav. \& Loan Ass'n v. Callander, 256 F.2d 410, 414-15 (5th Cir. 1958) (judicial acknowledgement that the scale of the regulator's formal powers was so great that far-reaching informal sanctions, including displacement of the entire management of the institution, could be coerced from an institution, even without direct statutory authority). See generally, e.g., Lawrence G. Baxter, Judicial Responses to the Recent Enforcement Activities of the Federal Banking Regulators, 59 FORDHAM L. REV. S193, S195-98 (1991) (describing the informal regulatory régime within which banking enforcement took place until the late-1960s).

17. On the evolution of the reform process, see infra text accompanying notes 110-28 and, for a fuller description of these powers, see MiCHAEL P. MALLOY, THE CORPORATE LAW OF BANKS 110-41 (Supp. I 1991) [hereinafter MALLOY Supplement].

Some commentators have expressed concerns that these powers are so extensive in their application as to violate fundamental principles of due process. See, e.g., Arthur W. Leibold, Where Have all the Due Process Rights Gone?, paper delivered to the American Banker-Bond Buyer Conference ("Deposit Insurance Reform in an Environment of Bank Restructuring,") Washington, D.C. (Apr. 22-23, 1991) (on file with author). To date, however, courts have rejected the constitutional claims made against enforcement orders. See, e.g., Akin v. Office of Thrift Supervision, 950 F.2d 1180, 1185-86 (5th Cir. 1992); Spiegel v. Ryan, 946 F.2d 1435, 1439-42 (9th Cir. 1991), cert. denied, 112 S. Ct. 1584 (1992); Parker v. Ryan, 760 F. Supp. 1189, 1192-93 (N.D. Miss. 1991); Paul v. Office of Thrift Supervision, 763 F. Supp. 568, 571-73 (S.D. Fla. 1990).

18. Federal Deposit Insurance Corporation Improvement Act of 1991 ("FDICIA"), 12 U.S.C.A. \& 18310 (West Supp. 1992). These powers can (and, in some cases, must) be exercised well before an institution is technically insolvent and subject to conservatorship or receivership. They include the ability to make a range of entrepreneurial-type decisions, such as displacing the management of the institution, restricting the interest rates the institution may pay on deposits, forcing new stock issues, and requiring the institution to divest itself of subsidiaries, and they include the mandatory imposition of receivership when the capital level of an institution falls below a certain level and the institution remains in that condition for a specificied period of time. 
demand it, against the institutions, their officers and directors, and related third parties such as attorneys, accountants, and appraisers. ${ }^{19}$

First, the regulators may issue temporary and permanent cease and desist orders. ${ }^{20}$ These remedies, though injunctive in form, can also include directives to take affirmative corrective action involving payment of restitution or reimbursement, or to provide indemnification and guaranty against potential losses on the part of the institution. ${ }^{21}$ The remedies may be made against institutions or individuals, or both, and a temporary order can be used effectively to "freeze" the assets of the institution ${ }^{22}$ or to secure immediate restitution, even before the merits of the enforcement action have been decided. ${ }^{23}$ The agencies can also apply to court for orders attaching the assets of institutions or individuals. ${ }^{24}$ In addition, the agencies can order the suspension or permanent removal of individuals from their offices or relationships with depository institutions, and they can prohibit any future participation by such persons in activities related to the banking industry. ${ }^{25}$ Finally, they are able to impose huge civil money penalties on both institutions and individuals, with these penalties ranging up to $\$ 1$ million per day. ${ }^{26}$ As with the other enforcement powers already mentioned, these penalties are imposed through the agency process, without the need for determination by the courts. ${ }^{27}$

It is not only the severity and range of sanctions that has been increased; their reach was also significantly extended in 1989 when Congress enacted the "S\&L Bailout" legislation. ${ }^{28}$ This legislation expressly authorized removal and prohibition orders to be made on an industry-wide basis ${ }^{29}$ and enforcement action against individuals who have already resigned from their positions or terminated their relationship with the depository institution in question. ${ }^{30}$ Most

19. Officers, directors, and certain outside third parties are now defined as "institution-affiliated parties." See infra text accompanying notes 31-32.

20. 12 U.S.C. $\$ \$ 1818$ (b) (permanent orders), 1818(c) (Supp. II 1990) (temporary orders). See infra Statutory Appendix.

21. 12 U.S.C. $\S \S 1818(b)(6),(7)$. See infra Statutory Appendix.

22. 12 U.S.C. $\$ 1818$ (c). See infra Statutory Appendix. This power was used very effectively by the OTS to force Kaye, Scholer to the bargaining table. See supra note 5.

23. See, e.g., Spiegel v. Ryan, 946 F.2d 1435 (9th Cir. 1991), cert. denied, 112 S. Ct. 1584 (1992) (upholding order requiring immediate payment by former officer of savings and loan of $\$ 21$ million, pending determination of final cease-and-desist order). The authority under which the agencies now act is even more explicit than it was in Spiegel, since the doubts that had been raised in the lower court (Spiegel v. Ryan, 1990 U.S. Dist. LEXIS 14968 (C.D. Cal. Aug. 3, 1990) (summarized in 55 BNA Banking Rep. 306 (1990)) were eliminated by Congress in the Crime Control Act of 1990, Pub. L. No. 101647, \& 2596(b) 104 Stat. 4789, 4908 (amending 12 U.S.C. \& 1818 (Supp. II 1990)).

24. 12 U.S.C. $\$ 1818(i)(4)$ (Supp. II 1990). See infra Statutory Appendix.

25. 12 U.S.C. \$ 1818(e) (Supp. II 1990). See infra Statutory Appendix.

26. 12 U.S.C. \& 1818(i)(2). See infra Statutory Appendix.

27. The assistance of the district courts is required to enforce these orders (see, e.g., 12 U.S.C. $\&$ 1818(d)), and it is possible to challenge the agency determinations in the courts of appeals on judicial review (see, e.g., 12 U.S.C. \$ 1818(h)(2) (Supp. II 1990)). See generally, Baxter, supra note 16, at S208-16.

28. Financial Institutions Reform, Recovery and Enforcement Act ("FIRREA"), Pub. L. No. 101-73, 103 Stat. 183 (1989).

29. See 12 U.S.C. \& 1818(e)(7).

30. See id. \& 1818(i)(3). 
important of all, Congress introduced the concept of an "institution-affiliated party," a concept that includes not only directors and officers, but employees, agents, and any other person "who participates in the conduct of the affairs of an insured depository institution," all of whom are subject to enforcement action. $^{31}$ Independent contractors such as accountants and attorneys are expressly included in the definition of institution-affiliated parties. ${ }^{32}$

\section{III}

\section{ENFORCEMENT POWERS AND FIDUCIARY DUTIES}

The banking business involves a number of fiduciary relationships. The exact scope of the fiduciary duties owed by persons associated with banking is important in the enforcement context because some, but not all, of the enforcement provisions authorize enforcement action where there has been a breach of fiduciary duty. $A l l$ the remedies and sanctions just described may be used against institutions and institution-affiliated parties in at least two generic situations: (1) when they have committed violations of the applicable law and regulations pertaining to the industry; and (2) when they are engaging in unsafe or unsound banking practices. In addition, two of the enforcement powers-removal and prohibition powers, ${ }^{33}$ and the civil money penalty sanctions ${ }^{34}$-may be wielded (3) when an institution or institution-affilitiated party has breached a fiduciary duty. ${ }^{35}$ This includes institution-affiliated parties who have participated in breaches of fiduciary duties that cause more than minimal loss to, or adversely affect, insured depository institutions. ${ }^{36}$

Fiduciary duties have long been relevant to the banking industry. Although "careful distinctions have not always been drawn," either as to the equitable and common-law sources of management responsibility, or as to their state- or federal-law basis, ${ }^{37}$ it is generally acknowledged that directors and officers owe some forms of fiduciary duties of care, loyalty, and good faith to their institutions. $^{38}$ One of the most frequent bases for enforcement action and litigation against former directors and officers by institutions in receivership is disloyal selfdealing and related forms of insider abuse. ${ }^{39}$ The trust departments of banks

31. Id. § 1813(u) (Supp. II 1990). See infra Statutory Appendix.

32. 12 U.S.C. $\& 1813(\mathrm{u})(4)$.

33. See id. § $1818(\mathrm{e})(1)(\mathrm{A})(\mathrm{iii})$.

34. See id. $\S \S 1818(\mathrm{i})(2)(\mathrm{B})(\mathrm{i})(\mathrm{III}),(\mathrm{i})(2)(\mathrm{C})(\mathrm{i})(\mathrm{III})$.

35. The sanction that encompasses the most "equitable" of all the remedies, namely the cease and desist power, which includes the power to order restitution and reimbursement in the event of unjust enrichment and the like, 12 U.S.C. $\$ 1818(\mathrm{~b})(6)(\mathrm{A})$, is predicated upon violations of law and unsafe and unsound practices and not breaches of fiduciary duty. See id. $\S 1818(\mathrm{~b})(1)$. The significance of this is examined further infra text accompanying notes 111-21.

36. 12 U.S.C. $\$ 1813(u)(4)$.

37. 1 Michael P. Malloy, The Corporate Law of BanKs 197 (1988).

38. Bowerman v. Hamner, 250 U.S. 504, 511-13 (1919); Briggs v. Spaulding, 141 U.S. 132 (1891). See generally, 1 MALLOY, supra note 37, at 197-202, 226-39; MALLOY Supplement, supra note 17, at 8587, 106-14.

39. For a recent example, see Jameson v. Federal Deposit Insurance Corporation, 931 F.2d 290 (5th Cir. 1991). C $f$. Report of the Senate Committee on Banking, Housing, and Urban Affairs 
obviously also owe fiduciary duties to their beneficiaries. ${ }^{40}$ It is even possible that, in addition to the duties arising from the debtor-creditor relationship, banks owe some limited fiduciary obligation to their depositors. ${ }^{41}$ Under certain circumstances, banks owe duties to borrowers and other customers that might aptly be characterized as "fiduciary." 42

In all these instances, however, the fiduciary duties in question are owed to private beneficiaries, such as shareholders, depositors, borrowers, investors, and the institutions themselves. Little difficulty has arisen where a regulatory agency has relied upon a breach of fiduciary duty owed to a third party, either to take direct agency administrative enforcement action against the institution or its management, or to sue as receiver for the institution (in the event of failure) to secure restitution to the institution of the profits derived from, or losses suffered as a result of, breaches by directors, officers, and employees. The controversy arises, however, with the position taken by some federal banking regulators that a general fiduciary duty is also owed, both by depository institutions and their affiliated parties, to the "federal insurer," meaning, in effect, the primary federal banking regulator and, at least secondarily, the FDIC. ${ }^{43}$

ON S.543, S. REP. No. 167, 102d Cong., 1st Sess. 55 (1991) (on the Federal Deposit Insurance Corporation Improvement Act of 1991). The underlying fiduciary nature of many of these enforcement actions is obscured by the fact that the duty of loyalty in lending transactions is fairly heavily codified by provisions such as those to be found in 12 U.S.C. $\$ \$ 375$ a \& 375b (1988 \& Supp. III 1991) (dealing with extensions of credit to insiders such as directors, executive officers and influential shareholders, the latter provision having been extensively rewritten in 1991 by FDICIA, \& 306).

40. See, e.g., 12 C.F.R. $\$ 9$ (1992) (Comptroller's regulations governing the exercise of trust powers by national banks enjoyed by virtue of 12 U.S.C. $\$ 92 a$ ). See generally, e.g., 2 MALLOY, supra note 37, at 603-12; EDWARD L. SyMONS \& JAMES J. WHITE, BANKING LAW 284-319 (3d ed. 1991).

41. See Commercial Cotton Company v. United California Bank, 209 Cal. Rptr. 551, 554 (Cal. Ct. App. 1985) (stating that "[t]he relationship of bank to depositor is at least quasi-fiduciary"). For subsequent judicial debate concerning this novel assertion, see, e.g. Lee v. Bank of America, 267 Cal. Rptr. 387, 392-96 (Cal. Ct. App. 1990) (Johnson, A.J., concurring and dissenting); Price v. Wells Fargo Bank, 261 Cal. Rptr. 735, 739-42 (Cal. Ct. App. 1989).

42. See Deborah A. DEMOTT, FIDUCLARY OBLIGATION, AGENCY AND PARTNERShIP ch. 5 (1991), especially 409-10 (duty of lender to act in a fiduciary capacity toward debtor where it has become the monopolist of credit to the borrower), 443-50 (bank lender's duty to disclose facts material to transaction with customer where it stands to benefit and a relationship of trust and confidence has developed between customer and bank), 450-56 (clearing bank's duty to disclose possible securities fraud by dealer on one of its customers). See also PETER D. MADDAUGH \& JOHN D. MCCAMUS, THE LAW OF RESTITUTION 580-82 (1990) (discussing Canadian judicial recognition of a fiduciary duty owed by banks to their customers).

43. Harris Weinstein, Address at Southern Methodist University in Dallas, Texas (Sept. 13, 1990), in Speech by OTS Chief Counsel Weinstein on Duties of Depository Institution Fiduciaries, 55 BNA BANKING REP. 508, 510 (1990) [hereinafter Weinstein Speech]; see also Bank, Thrift Attorneys React to Duties Outlined by OTS Chief Counsel Weinstein, 55 BNA BANKING REP. 547 (1990); Advice on How to Exploit Loopholes May Be Unethical, OTS' Weinstein Says, 56 BNA BANKING REP. 616 (1991); Ohio, Louisiana Draft Bills Would Limit Liability of Bank and Thrift Attorneys, 56 BNA BANKING REP. 765 (1991) [hereinafter Draft Bills]. Cf. FDIC Will Target Attorney Malpractice, Agency Counsel Cautions Banking Lawyers, 54 BNA BANKING REP. 545 (1990) [hereinafter Attorney Malpractice] (reporting remarks by an associate general counsel of the FDIC). It is not clear whether the other regulators are in agreement with the OTS. See Baxter, supra note 16, at S235 n.230 (citing reports indicating possible differences of opinion between the OTS, OCC, and FDIC).

This fiduciary duty doctrine was expressly relied upon by the OTS as the basis for one of its charges against Kaye Scholer. See Notice of Charges, In the matter of Fishbein, Katzman, Fisher \& Kaye, 
This general "fiduciary" duty adds one more dimension to the alreadycomplex structure of banking fiduciary duties-the fiduciary duty extending to the federal insurer is claimed, not on behalf of the institution, as is the case when the federal insurer is also the institution's receiver, but directly by the federal agency itself. ${ }^{44}$ Where the interests of the institution itself, or at least its shareholders, diverge from those of the insurer, as is inevitably the case when the institution is in danger of becoming insolvent, ${ }^{45}$ the fiduciary duties owed by management to the institution, its owners, and the federal insurer, are also likely to clash.

\section{IV}

\section{IS A GENERAL "FiduCIARY" DUTY OWED TO THE "FedERAL INSURER"?}

The claim that the federal bank regulators are the beneficiaries of a general fiduciary duty has been strenuously challenged, both insofar as the underlying fiduciary duty to the federal insurer is concerned ${ }^{46}$ and with regard to the corresponding liability of institution-affiliated parties, particularly attorneys. ${ }^{47}$ At least three questions are raised by the debate: (1) Is it even plausible to claim that a fiduciary duty is owed by insured institutions to the federal insurer? (2) Does the enforcement regime require, contemplate, or even accommodate the fiduciary duty? and (3) What additional protection would the claimed fiduciary duty add? This article answers these questions as follows: (1) that the claim to a general fiduciary duty is theoretically plausible; (2) Congress has, however, already provided for the regulators' concerns by means of a specific statutory duty to act safely and soundly and has deliberately confined the use of the concept of fiduciary duty to the latter's more traditional contexts; and (3) in any event, the fiduciary duty, properly interpreted, would impose no more substantive responsibility than that already demanded by statute.

\section{A. Is It Plausible to Claim that Insured Depository Institutions Owe a Fiduciary Duty to the Federal Insurer?}

There is no doubt that insured depository insitutions and their affiliates are under a duty, enforceable by the appropriate federal banking agency, not to

Scholer, Fierman, Hays \& Handler, OTS AP No. 92-19 at 26, I 54 (Mar. 1, 1992). See also Order to Cease and Desist, In the matter of Fishbein, Katzman, Fisher \& Kaye, Scholer, Fierman, Hays \& Handler, OTS AP No. 92-24 at 12, I 16(ii) (Mar. 11, 1992) (consent order imposing condition that "the fiduciary duties of [employees, officers, and directors of insured depository institutions] include the responsibility for the safety and soundness of the insured depository institution which, in turn, precludes transactions that pose an undue risk of loss to the depositors and/or the federal insurance fund").

44. The directness and independence of this duty, as envisaged by the regulators, is not entirely clear. Mr. Thomas, of the FDIC, seems to argue that in the case of attorney liability, the duty is derivative, with the FDIC as actual or potential receiver merely becoming the beneficiary of whatever fiduciary duties there might be owed by the attorney to the client institution. See Attorney Malpractice, supra note 43 , at 546.

45. See infra text accompanying notes 76-78.

46. See Nussbaum, supra note 7 .

47. See generally infra text accompanying notes $145-52$. 
violate relevant banking laws and regulations or engage in conduct that is unsafe or unsound. ${ }^{48}$ There is also no doubt that the relevant agency has the power to take enforcement action in an effort to extricate an institution from an unsafe and unsound condition. ${ }^{49}$ But it is a different question whether the agency may demand the discharge of a fiduciary duty in its own favor. Might such a duty exist?

The chief proponent of the view that a fiduciary duty is owed to the federal insurer, Harris Weinstein, Chief Counsel of the OTS, bases his assertion on three "hornbook principles." First, the federal insurer is subrogated to the rights of depositors, who would themselves have the right to seek restitution and money damages from their bankers. ${ }^{50}$ Second, "[b]y providing deposit insurance, the federal government has assumed a major equity position in every insured depository institution." 51 By analogy, therefore, the institution and its management owe a fiduciary duty to the federal government, which in these days has an "unlimited negative equity risk." 52 Third, as a depository institution nears the brink of insolvency, it assumes fiduciary responsibilities towards its creditors and,

just as the interests of creditors in the administration of a bankrupt estate are, by law, of paramount concern to the fiduciaries of that estate, so should the fiduciaries of an insolvent or close to insolvent thrift institution be primarily concerned with the interests of that institution's largest creditor, e.g., the U.S. government. ${ }^{53}$

Each of these principles, Mr. Weinstein argues, establishes a general fiduciary duty "not to risk insolvency and the resulting loss of funds deposited with the institution." $" 54$

The arguments against the existence of such a duty may be placed into two groups. The first invokes corporate theory and questions whether the adoption of a fiduciary duty in favor of the regulators would undermine the structure of efficient corporate responsibility. The second group of objections, and the one upon which this article focuses, questions whether it is possible to use Mr. Weinstein's eclectic approach to analogize the existence of one general fiduciary duty, and questions whether, even if this were possible, there is any room for the analogy within the existing statutory framework.

1. Corporate Theory Objection. The objection based on corporate theory is that any general fiduciary duty that exists is one owed, not to the federal agency,

48. On the unsafe and unsound concept, see further infra text accompanying notes 92-102.

49. 12 U.S.C. $\S \S 1818(b)(6)$ (affirmative action to correct conditions resulting from unsafe and unsound practices); 12 U.S.C.A. $\$ 18310$ (prompt corrective action in case of undercapitalized institutions; see supra note 18).

50. See Weinstein Speech, supra note 43, at 511.

51. Id.

52. Id.

53. Id.

54. Id. 
but to the shareholders. ${ }^{55}$ When the institution is at the "doorstep of insolvency," the interests of the shareholders almost inevitably conflict with those of the depositors and the insurer. And so, the argument goes, the institution, its management, and other affiliated parties cannot be under conflicting fiduciary duties, and the insurer should, therefore, content itself with whatever rights, through subrogation, it might have under the debtor/creditor contract between the depositors and the institution, and whatever rights or powers it might have under the regulatory "contract" constituting the federal banking statutes.

This view relies heavily upon a "contractual" model of fiduciary duty, in terms of which such duties exist essentially as "gap-fillers" where the contract between equity holders and the institutional management encounters unforeseen events. $^{56}$ As Professors Easterbrook and Fischel once put it, "the fiduciary principle is fundamentally a standard term in a contract to which the investors are parties." 57 In this view, the notion of fiduciary duty is dependent upon a construction of the investment contract, and this is a matter of the relationship between the institution, its management, and the investors-not the federal government. Any claims that the government might have would depend, instead, upon the debtor/creditor contract (to which the government accedes upon failure of the institution) and its own statutory contract forged on its behalf with the institution. ${ }^{58}$ Neither contract, it is argued, needs the assistance of a fiduciary duty on the part of the institution, its management, or its affiliated parties. ${ }^{59}$ Of course, the existence of a fiduciary duty might well be discernible as a "standard term" within the framework of the "statutory contract" anyway. But, the argument against the fiduciary duty continues, even if there is statutory ambiguity, the most efficient conclusion for a court to draw is that the "gapfilling" fiduciary duty should run to the benefit of the shareholders alone, since the other parties are in a relatively efficient position to protect themselves by contractual terms or regulatory action. ${ }^{60}$

There are difficulties with this line of argument. In the first place, it is premised upon a model of fiduciary duty that is not only historically very questionable but also contradicted by significant contemporary case decisions. ${ }^{61}$ The fiduciary concept was developed in equity from the primary concept of the trust and in counterpoint to the common law concepts of contractual obligation. It was never conceived as a "gap-filler." Rather, it comprised an overlay as the principle of "conscionability" that was designed to ensure that the obligor

55. See, e.g., Nussbaum, supra note 7, at 366. See also JONAThAN R. MACEY \& GeOFFREY P. Miller, BANKING LAW AND REGULATION 288-91 (1992).

56. See, e.g., Nussbaum, supra note 7, at 359-62.

57. Frank H. Easterbrook \& Daniel R. Fischel, Corporate Control Transactions, 91 YALE L.J. 698, 702 (1982).

58. Nussbaum, supra note 7 , at $367-68$.

59. Id.

60. Id. at 359-71.

61. See Deborah A. DeMott, Beyond Metaphor: An Analysis of Fiduciary Obligation, 1988 DUKE L.J. 879. 
discharged duties of loyalty, confidence, and trust, even if the obligor's rights at common law might expressly have permitted otherwise. ${ }^{62}$

In other words, the repository of such a duty is expected to "do the right thing." This duty is traditionally imposed on the fiduciary in circumstances that might place the fiduciary's loyalty to the beneficiary under challenge. Hence, the absence of contractual or statutory support for the fiduciary principle is not dispositive as to whether such a duty exists. ${ }^{63}$

Secondly, the "gap-filler," "efficiency" argument makes too much of the need for a unique and unidirectional duty owed by management to shareholders. The duty to equity holders is not the only fiduciary duty to which the institution or its management have traditionally been subject. ${ }^{64}$ There are, for example, many occasions arising in the trust-department activities of banks when institutional self-dealing would enhance the interests of the shareholders by securing greater profits for the institution, but would also constitute a clear breach of fiduciary duty owed to the trust beneficiaries. To the extent that such other fiduciary duties conflict with the fiduciary duty to shareholders, they modify the latter duty, and the shareholders' interests are correspondingly reduced. It follows that more, equally inconsistent, fiduciary duties, including duties in favor of the federal insurer, depositors, general creditors, or other parties, ${ }^{65}$ could also

62. See id.; see also L.S. Sealy, Fiduciary Relationships, 1962 CAMBRIDGE L.J. 69; Austin W. Scott, The Fiduciary Principle, 37 CAL. L. REV. 539 (1949).

63. The relationship between the entrustor and fiduciary, and the former's vulnerability to abuse of power at the hands of the latter, gives rise to the fiduciary relationship. See, e.g., Tamar Frankel, Fiduciary Law, 71 CAL. L. REV. 795, 810 (1983):

It is important to emphasize that the entrustor's vulnerability to abuse of power does not result from an initial inequality of bargaining power between the entrustor and the fiduciary. In no sense are fiduciary relations and the risks they create for the entrustor similar to adhesion contracts or unfair bargains. The relation may expose the entrustor to risk even if he is sophisticated, informed, and able to bargain effectively. Rather, the entrustor's vulnerability stems from the structure and nature of the fiduciary relation. The delegated power that enables the fiduciary to benefit the entrustor also enables him to injure the entrustor, because the purpose for which the fiduciary is allowed to use his delegated power is narrower than the purposes for which he is capable of using that power.

See also id. at 817 (discussing situations where fiduciary duties arise in the absence of contract).

64. See supra text accompanying notes $37-42$.

65. One seemingly obvious possibility might be the depositors in a mutual savings association, where the depositors are the "owners." The relationship between banks and their depositors has always been regarded as a debtor/creditor relationship, but one might expect that in the special case of depositors in mutuals some fiduciary relationship, arising out of their ownership of the mutual, might also be recognized. Yet, even here, the courts have rejected fiduciary-related claims by depositors.

Although the depositors are the legal "owners" of a mutual savings and loan association, their interest is essentially that of creditors of the association and only secondarily as equity owners. They are not allowed to realize or share in the profits of the association, but are entitled only to an established rate of interest. The depositors do not share in the risk of loss since their deposits are federally insured, and their only opportunity to realize a gain of any kind would be in the event the savings and loan association is dissolved or liquidated. As to this remote possibility the Supreme Court stated,

It stretches the imagination very far to attribute any real value to such a remote contingency, and when coupled with the fact that it represents nothing which the depositor can readily transfer, any theoretical value reduces almost to the vanishing point.

York v. Federal Home Loan Bank Bd., 624 F.2d 495, 499-500 (4th Cir.), cert. denied, 449 U.S. 1043 (1980) (quoting Society for Savings v. Bowers, 349 U.S. 143, 150 (1955)). See also Paulsen v. Commissioner, 716 F.2d 563, 569 (9th Cir. 1983); Wechsler v. Murray, 547 N.Y.S. 2d 497, 500 (N.Y. Sup. Ct. 
coexist with the fiduciary duty to shareholders, and that the latter duty would simply be the poorer for, or qualified by, all of them. This might be "inefficient," but it is a more realistic representation of the conflicting societal demands in a complex business environment.

\section{Even if One Does Not Accept the Corporate Responsibility, "Efficiency"} Argument, a Number of Problems with Mr. Weinstein's Reasoning Remain. ${ }^{66}$ In the first place, the authorities Mr. Weinstein cites in support of his "hornbook principles" do not support the conclusions he draws from them. The foundational case cited by Mr. Weinstein in support of a general fiduciary duty is Briggs $v$. Spaulding. ${ }^{67}$ The case involved an action by the receiver of an insolvent national bank against former directors of the bank for alleged breaches of their fiduciary duties. ${ }^{68}$ A narrowly divided court implicitly rejected the proposition that the directors occupied the position of trustees vis- $\dot{a}$-vis shareholders, ${ }^{69}$ though it is likely that the dissent by Justice Harlan, which would have imposed trustee-like duties on the directors, ${ }^{70}$ is rather closer to modern expectations of corporate responsibility. ${ }^{71}$ In any event, Briggs can hardly be regarded as support for the proposition that the "officers and directors of depository institutions are held to a strict fiduciary duty to act in the best interest of the institution, its shareholders and its depositors."72

The cases cited by Mr. Weinstein in support of the specific propositions that the federal insurer enjoys the benefit of a fiduciary duty as subrogee to the depositors, and that a bankruptcy trustee owes a fiduciary duty to creditors of the bankrupt estate, likewise establish little. The insurance cases do no more than illustrate the undisputed proposition that an insurer is subrogated to the rights of the insured against third parties. ${ }^{73}$ The FDIC and the RTC regularly sue for breaches of fiduciary duty owed by former directors and officers to the institutions under their receiverships, ${ }^{74}$ but this is not the kind of free standing,

1989) (East New York Savings Bank Depositors Litigation).

66. See also Nussbaum, supra note 7, at 383-91 (carefully exposing the deficiencies in each of Weinstein's arguments presented in support of the duty). As Mr. Nussbaum states, "[the] sheer breadth, and contradictory nature, of these characterizations, suggests that the OTS has embarked on a highly speculative course to identify the roots of the fiduciary duty it seeks." Id. at 390 .

67. 141 U.S. 132 (1891). See Weinstein Speech, supra note 43, at 510 n.3.

68. The actual formulation employed in the bill was breach of "common law duties as trustees of a financial corporation." Briggs, 141 U.S. at 142.

69. Id. at 148-49.

70. Id. at $173-74$.

71. See, e.g., Robert C. Clark, Corporate LaW 141 (1986).

72. Weinstein Speech, supra note 43, at 510 n.3.

73. Only one of the cases cited, Employer Mut. Liab. Ins. Co. of Wis. v. Indemnity Ins. Co. of N. Am., 234 N.Y.S.2d 839, 843 (N.Y. Sup. Ct. 1962), actually even discusses subrogation, although rather perfunctorily, as a principle of law.

74. See, e.g., David R. McAtee \& Robert B. Krakow, Should Bank Directors and Officers be Held Liable for Ordinary Negligence?, 4 BANKING L. REV. 33 (1992) (discussing some of these suits and the standards of liability involved); Charles F. Byrd \& Isabella W. Sammons, FDIC Legal Action Against Attorneys and Other Professionals, 108 BANkING L.J. 420 (1991); Arthur W. Leibold, Jr., Lessons from the Chilling Past (unpublished manuscript on file with author) (analyzing many of the issues and difficulties associated with pending suits by the FDIC and RTC). 
fiduciary duty being asserted by the regulators. Moreover, using the bankruptcy analogy ${ }^{75}$ would prove far too much: it is the RTC and the FDIC in their receivership capacities that would be subject, as "bankruptcy trustees," to the burden of this duty!

Second, the separate "hornbook principles" would not each imply the same general duty. The problem with Mr. Weinstein's three prongs of support for the fiduciary duty is that the director/shareholder, insurer/insured, and bankruptcy trustee/creditor duties each embrace discrete responsibilities with different implications and beneficiaries. It simply will not do to analogize from these specific fiduciary duties a general fiduciary duty to "the institution, its shareholders ... its depositors ... [and] the federal insurer"76 (in other words, everyone!). ${ }^{77}$

Third, one of Mr. Weinstein's more plausible arguments in favor of a general fiduciary duty is based on a premise that would preclude its operation in many of the situations where he would want to rely on it. It is perhaps possible to devise a potential case for a fiduciary duty in favor of the federal insurer that is based on the state of solvency of the institution. ${ }^{78}$ Now that the chickens are coming home to roost in this post-LBO era, support is growing for the imposition of a fiduciary duty on management, in favor of the institution's creditors, when the institution approaches the brink of insolvency and the incentives on managers cause them to adopt strategies that lead to negative-net-present-value investments. $^{79}$ Where the equity level has fallen so low, and the likelihood of receivership and the loss of their property and offices has become so high, it becomes worthwhile for shareholders and managers to engage in high-risk strategies that are contrary to the interests of creditors, who are the only real stakeholders left. To protect creditors, therefore, it is also at this point that the

75. See, e.g., In re Consupak, Inc., 87 B.R. 529, 546 (Bankr. N.D. Ill. 1988).

76. Weinstein Speech, supra note 43, at 510-11.

77. Here one cannot resist invoking the oft-quoted dictum of Justice Frankfurter: "to say that a man is a fiduciary only begins the analysis; it gives direction to further inquiry. To whom is he a fiduciary? What obligations does he owe as a fiduciary?" SEC v. Chenery Corp., 318 U.S. 80, 85-86 (1943).

For an analysis of the further difficulties associated with Mr. Weinstein's specific analogies, see Nussbaum, supra note 7 , at 383-91.

78. See Weinstein Speech, supra note 43, at 511.

79. See Credit Lyonnais Bank Nederland, N.V. v. Pathe Communications Corporation, 1991 WL 277613 , at $* 33$ n.55 (Del. Ch. 1991): "At least where a corporation is operating in the vicinity of insolvency, a board of directors is not merely the agent of the residu[al] risk bearers, but owes its duty to the corporate enterprise [as opposed to its shareholders]." For a similar factual situation (though one apparently not invoking "fiduciary" principles), see In the Matter of Central Ice Cream Co., 836 F.2d 1068, 1069-71, 1072 n.3 (7th Cir. 1987).

Some support for this view might also be drawn from cases that have treated the favoring of shareholders during the period immediately preceding insolvency as a voidable act. See, e.g., Pepper v. Litton, 308 U.S. 295 (1939). Perhaps the seminal case from which support might be drawn in the banking context is Wood v. Dummer, 30 F. Cas. 435 (C.C.D. Me. 1824) (No. 17,944), in which Justice Story (on circuit) stated that "[i]t appears to me very clear upon general principles, as well as the legislative intention, that the capital stock of banks is to be deemed a pledge or trust fund for the payment of the debts contracted by the bank." Id. 436. 
fiduciary duty of the managers "springs" from the shareholders to the creditors. $^{80}$ In the case of federally insured banks, this fiduciary duty would therefore operate at least partly to the benefit of the federal insurer.

This is hardly a satisfactory basis for the general fiduciary duty, however, because the duty would operate only at the doorstep of insolvency. ${ }^{81}$ To rely upon the "doorstep of insolvency" test would lead to the result that the enforcement liability of the institution and its affiliated parties would rise and fall with the fluctuating fortunes of the institution itself. At what point would enforcement liability kick in? When the institution's capital level dropped below two percent? If the capital level rose the following day, would liability evaporate? The regulators would surely not wish to confine the general basis of their enforcement powers to so precarious a foundation. ${ }^{82}$

Finally, although there is another potential basis upon which the fiduciary duty might rest-namely, the need to protect the federal deposit insurance funds-its drawback is that the importance of this need has already led Congress to take care of the problem by interposing an unequivocal and constant statutory duty to observe principles of safety and soundness. If Congress had not acted, it might have been possible to go some distance toward fashioning the fiduciary duty from the need to protect the federal deposit insurance funds, and from the potential vulnerability of the federal regulators to abusive action by persons and institutions in control of deposits. ${ }^{83}$ It would not even be necessary to use, as does Mr. Weinstein, the doctrine of subrogation to link the rights of the insurer to the institution. The federal deposit insurance relationship is more aptly characterized as a relationship between the federal insurer and the depository institution itself, with the depositors being no more than beneficiaries in the event that payment of the insurance must be made. ${ }^{84}$ This is so because deposit

80. See generally Coffee, supra note 6 (advocating a fiduciary duty owed by the management to the creditors, instead of the shareholders, when the institution is under threat of insolvency).

81. Id. Outside of the context of threatened insolvency, this "springing" fiduciary duty would have little application.

82. The principle of safety and soundness, upon which enforcement liability is more appropriately based, provides a much more constant predicate. See infra text accompanying notes 92-121. For example, it would be unsafe and unsound to risk insolvency of the institution at any time, no matter how strong the institution was. Enforcement action would be appropriate if the management of a strong institution decided to "roll the dice" for a big win at the risk of collapsing the entire institution. Under the "springing" fiduciary doctrine, the management would not yet be under a fiduciary duty to the federal insurer.

83. Vulnerability is an important factor in identifying a fiduciary relationship. See, e.g., Frankel, supra note 63. See also the Canadian case of Frame v. Smith, 2 S.C.R. 99, 136, 99 (1987) (Wilson, J., dissenting):

Relationships in which a fiduciary obligation has been imposed seem to possess three general characteristics:

(1) The fiduciary has scope for the exercise of some discretion or power.

(2) The fiduciary can unilaterally exercise that power or discretion so as to affect the beneficiary's legal or practical interests.

(3) The beneficiary is peculiarly vulnerable to or at the mercy of the fiduciary holding the discretion or power.

84. Cf. Nussbaum, supra note 7 , at 385 (noting that this would be a firmer basis for the fiduciary duty, but rejecting this argument as well because it "defies economic logic" and is contrary to the general 
insurance was not created, and does not now function, merely to protect the "'hard earnings' entrusted by individuals to a bank." ${ }^{85}$ It was created to restore public confidence in depository institutions by making them commercially viable in the face of higher-paying, but more risky, alternative repositories of savings, and it was created for the public policy purpose of ensuring the restoration, as fast as possible in the event of bank failure, of the circulating medium. ${ }^{86}$

These concerns can be illustrated by numerous examples, of which the following are only a few. First, the commercial value of federal deposit insurance to banking institutions is evident from the phrase, "member, FDIC," which is ubiquitous in bank and thrift commercials. The franchise value of this slogan was the reason for the fierce battle that raged in 1989 between commercial banks and thrifts over the way in which FDIC insurance could be advertised. ${ }^{87}$ Secondly, the FDIC has a discretionary power to pay out more than the mandatory minimum insurance to protect the local economic environment within which a bank failure has occurred, ${ }^{88}$ this highlights the fact that the insurer's responsibility is to a much broader range of interests than those of the depositors alone. $^{89}$ Finally, except by deciding whether to deposit or not, depositors do not negotiate the terms of their deposit insurance, nor do they pay the premiums directly. Premiums are assessed on a fixed-rate basis and are paid according to the overall deposit base of each institution, and insurance is mandatory for the major portion of the depository institution industry. ${ }^{90}$

drift of possibly relevant cases).

85. Federal Deposit Insurance Corporation v. Philadelphia Gear Corp., 476 U.S. 426, 433 (1986) (quoting from remarks by Rep. Steagall during the floor debates in the House in 1933).

86. See Carter H. Golembe, The Deposit Insurance Legislation of 1933: An Examination of its Antecedents and its Purposes, 75 POL. SCI. Q. 181 (1960):

[I]t is clear from both the statements and actions of many proponents and administrators of bank-obligation insurance systems that the primary object has not been to guard the individual depositor or noteholder against loss but, instead, to restore to the community, as quickly as possible, circulating medium destroyed or made unavailable as a consequence of bank failures. In this view, bank-obligation insurance has a monetary function, and the protection of the small creditor against loss is incidental to the achievement of the primary objective.

Id. at 189 .

87. See, e.g., House Banking Votes to Tighten S\&L Capital Rules, Fund Low-income Housing Assistance, 52 BNA BANKING REP. 939, 944 (1989); U.S. League Recommends S\&Ls Advertise Themselves as FDIC-Insured Institutions, 53 BNA BANKING REP. 259, 263-64 (1989) (descriptions of the controversy); Lawmakers Receptive to Deposit Insurance Reform, Banking Officials, Experts Predict, 53 BNA BANKING REP. 259, 264 (1989) (FDIC adoption of final rule on new logo for thrifts).

88. 12 U.S.C. \& 1823(c) (Supp. II 1990). This power was substantially curtailed by the Federal Deposit Insurance Corporation Improvement Act of 1991, \& 141, 12 U.S.C. \& 1823(c)(4), which imposed the fetter of "least cost resolution" principles on the FDIC's discretion.

89. In order to appreciate fully the general, non-institution-specific monetary significance of this power, it would be necessary to consider the money-creating role of depository institutions, the notion of "systemic failure," and even the "too-big-to-fail" doctrine, all of which are beyond the scope of this article. See e.g., Keith R. Fisher, Reweaving the Safety Net: Bank Diversification into Securities and Insurance Activities, 27 WAKE FOREST L. REV. 123, 223-26 (1992).

90. Federal deposit insurance is now also virtually essential for any state chartered institution as well, even though it is not legally mandatory. 
Hence, it is appropriate to regard the insurance relationship in federal deposit insurance as primarily between the institutions themselves and the insurer, the FDIC. This is indeed the basis for the federal regulation by the FDIC and the OTS of federally insured state institutions. The deal that was struck from 1933 onwards, between depository institutions and the federal government, was that depository institutions would enjoy the benefit of flat-rate-premium insurance protection, with all the commercial advantages and stability that this protection might bring. The federal government would then be entitled to protect the insurance funds by subjecting the institutions to close regulatory scrutiny in order to ensure the continuing safety and soundness of the institutions themselves. Under this characterization, one might argue, the federal insurer should be entitled to the protection of whatever fiduciary duties a direct insurance relationship might bring.

\section{B. Does the Enforcement Regime Require, Contemplate, or Even Accommodate the Fiduciary Duty?}

Even if one could establish a general fiduciary duty, however, a close examination of the statutory enforcement structure reveals that the duty has long been overwhelmed by a fundamental regulatory principle distinctive to federally insured banking - namely, the duty not to engage in unsafe and unsound conduct. The duty to act safely and soundly is basically a duty not to take actions that might place the solvency of the banking institution in jeopardy. It is a duty that is already articulated throughout the labyrinth of federal banking legislation, and its violation is one of the most well-established bases for enforcement action. Unlike a duty based on fiduciary principles, however, the duty not to engage in unsafe and unsound conduct is determined not by reference to general principles of equity, but by reference to the intention and policies of Congress. ${ }^{91}$

"Unsafe and unsound" is, it is true, a concept that defies precise definition, ${ }^{22}$ being "largely a predictive judgment (i.e., what may happen if this practice continues)." ${ }^{93}$ It is a complex regulatory concept, delegated for specific

91. See Federal Deposit Insurance Corporation Act, Pub. L. No. 102-242, § 132, 105 Stat. 2267 (codified at 12 U.S.C.A. $\$ 1831$ p-1 (West Supp. 1992))("FDICIA"). For additional examples see infra note 94.

92. Congress has long been aware that the terms "'[u]nsafe' and 'unsound' have no definite or fixed meaning," SENATE COMMITTEE ON BANKING AND CURRENCY, FINANCIAL INSTITUTIONS SUPERVISORY ACT OF 1966, S. REP. No. 1482, 89th Cong., 2d Sess., reprinted in 1966 U.S.C.C.A.N. 3532, 3539, and has, therefore, sought to impose safeguards upon the exercise of enforcement powers when these are based on allegations of unsafe and unsound conduct. See, e.g., id. (explaining the added requirement of a finding of personal dishonesty before a suspension or removal order could be made against an officer or director under the 1966 legislation).

93. Franklin Sav. Ass'n v. Director, Office of Thrift Supervision, 934 F.2d 1127, 1146 (10th Cir.

1991). A classic description of the concept is that by John $E$. Horne, then chairman of the FHLBB:

Generally speaking, an "unsafe or unsound" practice embraces any action, or lack of action, which is contrary to generally accepted standards of prudent operation, the possible consequences of which, if continued, would be abnormal risk or loss or damage to an institution, its shareholders, or the agencies administering the insurance funds. 
formulation in discrete circumstances to the banking agencies themselves, ${ }^{94}$ but often also codified in specific terms by Congress ${ }^{95}$ or in agency rules. ${ }^{96}$ Despite its complex flexibility, the concept has survived challenge on constitutional grounds of vagueness because, as the Supreme Court put it in Fahey $v$. Mallonee, ${ }^{97}$ the "unsafe and unsound" concept and other related concepts are "regulatory. They do not deal with unprecedented economic problems of varied industries. They deal with a single type of enterprise and with the problems of insecurity and mismanagement which are as old as banking enterprise." ${ }^{18}$

It is important, when noting the flexibility inherent in the "unsafe and unsound" concept, to emphasize that this flexibilty is not identical to that stemming from the equitable nature of fiduciary duties. In the case of fiduciary duties, their content is ultimately determined by a supervising court that, as the exponent of equitable doctrine, wields the initiative in reaching final determinations concerning the application of such doctrine in individual cases. ${ }^{99}$ In the case of safety/soundness principles, the primary reference point is the intention of Congress; the question facing a court is not whether it (the court) regards an action or condition as unsafe and unsound, but whether the agency, given its statutory authority, has correctly concluded that it is. The actual limits of agency authority in each case will depend upon a matrix of legislative prescripts that will usually reflect carefully crafted congressional compromises. Congress frequently prescribes detailed safety/soundness principles; ${ }^{100}$ when an agency imposes requirements that reach beyond these principles and is struck down by a court on review, the agency must return to Congress to gain the additional authority

Memorandum submitted to the Chairman of the Senate Banking and Currency, 112 Cong. REC. 26,474 (1966).

94. The courts acknowledge the importance of deferring to the agencies' exercise of judgment in this formulation. See, e.g., Franklin, 934 F.2d at 1145-46; First Nat'l Bank of Lamarque v. Smith, 610 F.2d 1258, 1265 (5th Cir. 1980); Independent Bankers Ass'n of Am. v. Heimann, 613 F.2d 1164, 1168-69 (D.C. Cir. 1979), cert. denied, 449 U.S. 823 (1980); Groos Nat'l Bank v. Comptroller of the Currency, 573 F.2d 889, 897 (5th Cir. 1978).

95. The most important recent example is to be found in the 1991 Federal Deposit Insurance Corporation Improvement Act legislation, which enumerates a list of "standards for safety and soundness," relating to operation, management, asset quality, earnings, and stock valuation, that must be prescribed by the banking agencies. FDICIA, Pub. L. No. 102-242, § 132, 105 Stat. 2267 (codified at 12 U.S.C.A. \$ 1831p-1) (adding new $\$ 39$ to the Federal Deposit Insurance Act). For other examples, see FDICIA, \& 131(c), 105 Stat. 2266 (amending 12 U.S.C. \$ 1818(b)(8)) (stipulating that an institution receiving a "less-than-satisfactory rating for asset quality, management, earnings, or liquidity" may be deemed to be engaging in unsafe and unsound conduct); the International Lending Supervision Act of 198, Pub. L. No. 98-181, § 908, 97 Stat. 1280, 12 U.S.C. $\$ 3907$ (1988) (identifying capital adequacy requirements as appropriate safety and soundness requirements to be imposed by regulators).

96. See, e.g., Heimann, 613 F.2d at 1168-69 (power of regulator to enshrine safety and soundness requirements in rules).

97. 332 U.S. 245 (1947).

98. Id. at 250. See also, e.g., Farmers State Bank v. Bernau, 433 N.W.2d 734, 741 (lowa 1988) (reliance on such terms is not tantamount to proceeding without standards or acting on the basis of "secret law").

99. See, e.g., Frankel, supra note 63, at 823-24 (describing the active supervisory role of the court when ensuring observance of fiduciary duties).

100. See e.g., FDICIA, § 132, 12 U.S.C.A. \& $1831 \mathrm{p}-1$. 
it needs. ${ }^{101}$ In the case of a fiduciary duty, on the other hand, the delegation of power to a court and, in practice, to the agency ${ }^{102}$ is much fuller. The distinction is, therefore, not merely semantic.

Once the general safety and soundness duty becomes the focus, instead of the "fiduciary duty" asserted by the regulators, the whole enforcement puzzle fits together. The statutory enforcement structure can more easily be explained both in terms of its historical development and in terms of the structural interrelationship between the various enforcement powers available to the agencies.

As far as legislative history is concerned, bank regulation was initially enforced through the threat of "death-penalty" powers such as deposit insurance termination and receivership. ${ }^{103}$ But the combination of extremely severe formal sanctions and increasingly ineffective informal coercion proved inefficient as a means of regulating the complex industry. As a result, bank enforcement reform since mid-century has developed in three directions, extending: first, the array of enforcement sanctions; second, the targets of the sanctions; and, third, the grounds for taking enforcement action. Throughout this process, however, and even during the most heated period of reform in 1989 and 1990, Congress has always proceeded deliberately, adding only incrementally to the circumstances in which newly extended enforcement powers might be exercised.

The array of enforcement sanctions was gradually expanded from 1933 . For example, in 1954 the Federal Home Loan Bank Board ("FHLBB"), the predecessor to the OTS, was given the power to issue orders requiring compliance with federal law and regulations. ${ }^{104}$ This power proved slow and cumbersome, because thrifts were still able to require a trial de novo in a federal district court. In order to provide greater enforcement flexibility, ${ }^{105}$ the federal regulators were, in 1966, given permanent and temporary cease-and-desist powers, as well as general removal and suspension powers. ${ }^{106}$ Continuing in this vein, Congress augmented these powers in 1978 by allowing the agencies to

101. For example, the express safety/soundness mandate relating to capital requirements contained in the International Lending Supervision Act of $1983, \S 908$, supra note 95 , was a response to an adverse decision in the Fifth Circuit. See First National Bank of Bellaire v. Comptroller of the Currency, 697 F.2d 674 (5th Cir. 1983). See also Baxter, supra note 16, S212-13.

102. See infra text accompanying note 126.

103. See supra text accompanying notes 12-15.

104. Housing Act of 1954, Pub. L. No. 560-54, § 503, 68 Stat. 590, 635 (1954) (repealed 1966).

105. See, e.g., SENATE COMMITTEE ON BANKING AND CURRENCY, FinanCial InStitutions SUPERVISORY ACT OF 1966, S. REP. No. 1482, 89th Cong., 2d Sess. 1 (1966), reprinted in 1966 U.S.C.C.A.N. 3532, 3537-38 [hereinafter S. REP. No. 1482] (noting the deficiencies of the existing enforcement powers of the FDIC and the FHLBB); Hearings on H.R. 17899, Financial Institutions Supervisory and Insurance Act, Before the House Committee on Banking and Currency, 89th Cong., 2d Sess. 28-29 (letter from Chairman of the Fed), 29-30 (letter from Chairman of FDIC), 35-38 [hereinafter Statement of John E. Horne] (statement of John E. Horne, Chairman, FHLBB) (1966).

106. Financial Institutions Supervisory Act of 1966, Pub. L. No. 89-695, 80 Stat. 1028 (codified at 12 U.S.C. \& 1464(d) (1988)). 
impose limited civil money penalties. ${ }^{107}$ Finally, in 1989 and 1990 all of these powers were greatly enhanced. ${ }^{108}$

The targets of enforcement action were also steadily extended. In the 1966 reforms, the introduction of a general removal and suspension power enlarged the circumference of enforcement power from its primary focus on institutions, to cover the individuals within those institutions, as well. In 1978, the legislation that vested agencies with the power to impose civil money penalties also permitted them to wield their cease-and-desist powers against individual stockholders, officers, and directors. ${ }^{109}$ Then, in 1989, the enforcement net was greatly extended through the introduction of the "institution-affiliated party" concept and authority to apply the removal and prohibition powers against individuals who had already severed their relationship with the institution involved, such as directors who had resigned or attorneys who once acted for the institution. ${ }^{110}$

Even the grounds for enforcement action have also been steadily, but deliberately, extended. The regulatory agencies' powers were initially confined to cases where there were violations of "law and regulations," but soon the discretionary concept of "safety and soundness" was introduced as a basis for enforcement action. For example, the federal insurers acquired the power to terminate federal deposit insurance in cases of continuing unsafe and unsound conduct, without having to prove violations of law or regulations. ${ }^{111}$ In 1966 , however, the concept of fiduciary duty was introduced in the specific context of removal and suspension powers. This context explains a distinction that remains important: in the case of cease-and-desist authority, the basis for action was confined to the violation of law and regulations or safety and soundness principles; in the case of removal and suspension authority, the basis of fiduciary duty was added. ${ }^{112}$ This extra basis for action-breach of fiduciary duty - was also included when civil money penalties were first provided for in $1978 .{ }^{113}$

It is evident from the reports and debates comprising the legislative history of these reforms that this segregation of breach of fiduciary duty as a basis for enforcement action was deliberate. Congress was fully aware that the

107. Financial Institutions Regulatory and Interest Rate Control Act ("FIRIRCA") of 1978, Pub. L. No. $95-630,92$ Stat. 3641 .

108. See supra text accompanying notes $28-32$.

109. FIRIRCA \& 107, 92 Stat. 3649, 3649-64.

110. See supra text accompanying note 30 .

111. Federal Deposit Insurance Act of 1950 , Pub. L. No. $797-50, \S 8,64$ Stat. 879,12 U.S.C. \& 1818(a); National Housing Act of 1954, Pub. L. No. 560-54, $\$ 501$, 68 Stat. 633, 12 U.S.C. $\$ 1730$ (repealed 1989) ("FSLIC"). To this day, violations of law and unsafe and unsound conduct remain the primary bases for enforcement action.

112. See, e.g., Federal Institutions Supervisory Act of 1966, Pub. L. No. 89-695, \& 202, 80 Stat. 1046 (adding new subsection 8(e)(1) to the Federal Deposit Insurance Act of 1950) ("FISA"). In addition, provision was made for removal of a director or officer who had been convicted of a felony involving dishonesty. Id. (adding new subsection $8(\mathrm{~g})$ ).

113. See, e.g., FIRIRCA $\$ 107$ (d), 92 Stat. 3656. 
fundamental purposes of the enforcement powers are quite different. ${ }^{114}$ Ceaseand-desist authority has always been perceived to be remedial and designed in the first instance to preserve the welfare of the institution from unlawful or unwise management, whereas the removal power (and the civil money penalty sanction) admits the additional concern of the integrity of the management. ${ }^{15}$ For this reason, Congress first imposed the requirement that where breach of fiduciary duty was to be the basis for suspension and removal there be a showing, not merely of a breach of the duty, but of "personal dishonesty" on the part of the director or officer. ${ }^{116}$ The requirement of a showing of personal dishonesty was subsequently supplemented to facilitate the removal or fining of persistently inept or irresponsible, as well as dishonest, managers. ${ }^{117}$ But the laconic statutory language referring to breaches of "fiduciary duty" has never, even in the far-reaching enhancements of 1989 , been introduced into the provisions governing the agencies' cease-and-desist powers. ${ }^{118}$

The separate provision of fiduciary duty as a basis for removals, prohibition orders, and civil money penalties, and the deliberate omission of breaches of "fiduciary duty" from the cease-and-desist remedy, are significant. Coming against a primary and consistent concern for the maintenance of the safety and soundness of the nation's depository institutions, this statutory structure strongly suggests that Congress has always assumed that the safety/soundness principle took care of actions carrying risks of insolvency. It also strongly suggests that the "fiduciary duties" to which the removal, prohibition, and civil money penalty

114. For example, the new "intermediate" sanction powers conferred in 1966 were justified during the House floor debate as being necessary to protect not the regulatory agencies but depositors, the regulators having more than sufficient power to protect themselves. See 112 CONG. REC. 24,984 (1966).

115. After reviewing the recent experiences of the FHLBB in attempting to curb improper activities in the thrift industry, the Chairman of the FHLBB, in his testimony before the House Banking Committee in 1966, stated,

This case history may help make clear an important point - the cease-and-desist proceeding and the suspension-removal proceeding are not alternative ways of handling the same sort of problem, but are designed for quite different kinds of situations. When we learn of transactions showing that the person or group in control of an institution is lacking in the fundamental integrity demanded by a position of public trust and responsibility for millions of dollars of other peoples' savings, that person should be removed from office. It is both inappopriate and ineffectual to chase after him with cease-and-desist orders, telling him to stop robbing the association by one device but leaving him free to think up other maneuvers .... and use them for a while.

Statement of John E. Horne, supra note 105.

116. See, e.g., S. REP. No. 1482, supra note 105, reprinted in 1966 U.S.C.C.A.N. 3539 (explaining the need to add the requirement of personal dishonesty, the committee considering it undesirable that suspension and removal orders might issue "on the basis of nothing more than a difference of opinion about the most debatable of management problems").

117. FIRIRCA \$ 107(d) (permitting removal in the case of "willful or continuing disregard for the safety or soundness of the bank"). See H.R. Rep. No. 1393, 95th Cong., 2d Sess. 18 (1978), reprinted in 1978 U.S.C.C.A.N. 9273, 9290 ("This new standard will allow the agencies the opportunity to move against individuals who may not be acting in a fraudulent manner but who are nonetheless acting in a manner which threatens the soundness of their institution.").

118. See Nussbaum, supra note 7, at $381-82$ (noting deliberate mention of a "fiduciary duty" owed by directors or officers to a bank). 
powers refer are the well-recognized, discrete fiduciary duties owed to those private parties that already encrust the business of banking. ${ }^{119}$

This interpretation is also entirely compatible with the unusual structure of the definition of "institution-affiliated parties,"120 which refers to parties who "knowingly or recklessly" participate in violations of law, unsafe and unsound practices, and breaches of fiduciary duty. The "fiduciary duty" reference in the "institution-affiliated party" definition is there because the "institution-affiliated party" concept is intended to serve multiple purposes in connection with all four types of sanctions: cease-and-desist; suspension and removal; prohibition; and civil money penalties. There is no indication that this reference also extends to the cease-and-desist powers that, by their express terms, do not rely on the fiduciary duty concept at all. ${ }^{121}$

\section{What Additional Protection Would the Claimed Fiduciary Duty Have Added?}

Even if the putative general fiduciary duty had been allowed to flourish, it is difficult to identify what extra substantive protection this duty might have given to the insurance funds. Once the regulators' fiduciary duty doctrine is stripped to its essentials, it becomes clear that all the regulators seem to contemplate is that the institution's management, to protect the interests of the federal insurance fund, should avoid taking action that jeopardizes the solvency of the institution. Accordingly, this duty becomes ever more salient as the institution slides toward the brink of insolvency. Indeed, as Mr. Weinstein has himself stated, the fiduciary duty that he identifies for insured depository institutions is a duty "not to risk insolvency and the resulting loss of funds deposited with the institution."122

Yet, in the banking context, the duty thus characterized simply dissolves as a distinct duty. On either of the two most plausible bases already described, ${ }^{123}$

119. For examples, see supra text accompanying notes 38-42.

120. See infra 12 U.S.C. $\$ 1813(u)$, Statutory Appendix.

121. An irony regarding the cease-and-desist power is that the authority to impose a cease-and-desist order now expressly includes the power to order such quintessentially "equitable" remedies as restitution and reimbursement. See supra text accompanying note 21 . This express power had to be conferred by Congress in 1989, precisely because some courts had refused to recognize that cease-and-desist authority included the power to order equitable restitutionary relief. Financial Institutions Reform, Recovery \& Enforcement Act of 1989 ("FIRREA") \$ 902, 103 Stat. 450, 12 U.S.C. $\$ 1818(b)(6)$, (7) (1989). See Larimore v. Comptroller of the Currency, 789 F.2d 1244, 1255-56 (7th Cir. 1986) (en banc) (Comptroller lacked authority under cease-and-desist power to order directors personally to compensate bank for losses caused by their approval of excessive loans); Citizens State Bank v. Fed. Deposit Ins. Corp., 751 F.2d 209, 216-19 (8th Cir. 1984) (FDIC had no power to order bank to reimburse customers for overcharges arising out of technical Truth in Lending violations). Although the power now expressly conferred seems consistent with the general tendency by Congress to supply the banking agencies with "in-house" administrative enforcement powers, precluding the need for resort to the courts, the power had to be conferred in express terms because of the sui generis nature of the cease-and-desist power; it was not possible, in other words, to analogize very easily from equitable principles to identify more extensive, "implicit" statutory authority.

122. Weinstein Speech, supra note 43, at 511.

123. See supra text accompanying notes 78-90. 
the institution and its affiliates would merely be required to avoid action potentially exposing the institution to a significant risk of insolvency. As far as the fiduciary duty to creditors is concerned, the management of the institution and its shareholders would be under a duty not to "bet the ranch." Their obligation would instead be to act with increasing aversity to risk, so as to preserve the value of the realizable assets of the institution should a payoff to creditors become necessary. A fiduciary duty to the federal insurer, qua insurer, would include the duty to avoid acts (such as becoming insolvent) that create a serious risk to the insured assets-namely, the institution itself.

It turns out that this is exactly what seems to be envisaged by Mr. Weinstein in his assertion of the fiduciary duty. He gives an example of a savings bank that has had to increase its loan loss reserves to compensate for the declining value of its real estate portfolio in a depressed market. The bank has assets of $\$ 1$ billion and tangible capital of $\$ 5$ million ( 0.5 percent of assets). This bank is, by any measure, seriously undercapitalized and teetering on the brink of insolvency. The bank's management is presented with an opportunity to engage in a large urban residential development involving investment costs of $\$ 30$ million. If successful, the venture will bring a gross return of $\$ 55$ million and a net return of $\$ 25$ million, which would in turn improve the bank's capital to $\$ 30$ million and its capital-to-assets ratio to three percent. On the other hand, the venture is highly risky, and there is a significant possibility of failure. Failure would cost the institution the full $\$ 30$ million of its investment; this would, in turn, create a capital deficit of $\$ 25$ million ( -2.5 percent of assets). Anticipating (or merely hoping) that the economic downturn has almost bottomed out, the management would be inclined to "roll the dice," but this is exactly where, Mr. Weinstein argues, the fiduciary duty of the management and owners is to act in the interests of the institution's largest creditor, the government. The "only conscionable legal conclusion," Mr. Weinstein concludes, is that the directors owe a fiduciary duty to the federal insurer. ${ }^{124}$

Mr. Weinstein does not describe what course of action should be adopted in discharge of this duty. Obviously, the directors are expected to engage in some business activity; Mr. Weinstein, however, strongly suggests that the housing project should not be undertaken, despite its potentially high return, because the risk of insolvency is too great. In other words, it seems that the duty contemplated by Mr. Weinstein is merely to forsake any significant risk of insolvency, even where there is little left to lose from the management's and shareholders' points of view. ${ }^{125}$ Hence the fiduciary doctrine would, in substance, add

124. See Weinstein Speech, supra note 43, at 511-12.

125. Mr Weinstein's example itself unintentionally demonstrates why his general fiduciary duty is so problematic in the banking environment. The gamble, if it pays off, would have brought the institution's capital-to-assets ratio into compliance with minimum statutory requirements, see FIRREA $\S 301$ (cited as Home Owners Loan Act, $\S 5(t)(2)(A)$ ), and out of the zone in which the OTS would be required to take a much more active role in the management of the institution. See Federal Deposit Insurance Corporation Improvement Act of $1991 \S 131,12$ U.S.C.A. $\$ 18310$ (1989). Because of the continuing shortfall in funds available to cope with thrift failures, the OTS has an incentive, competing with the 
nothing to the protection of the insurance funds already provided for by Congress under its statutory safety/soundness requirements.

On the other hand, recognition of the doctrine would have profound practical enforcement advantages for the regulators, because it would enable the regulators to determine the content of the duty owed to them without regard to any potentially applicable state law standards of fiduciary duty. Since these determinations would be made by the regulators on the basis of the specific facts in each enforcement adjudication, agency case-by-case determinations concerning the contents of the duty would enjoy deference from reviewing courts. The banking agencies would, as a result, be able to develop a kind of "federal administrative common law" upon which they could base their enforcement actions against institutions and institution-affiliated parties. ${ }^{126}$

The battle to secure the power to develop a federal administrative common law of fiduciary duty has been raging for some time. ${ }^{127}$ In a recent enforcement order, the OTS explicitly declared that directors of federally insured savings institutions are governed by a federal standard of fiduciary duty, ${ }^{128}$ and the OCC appears to hold the same view. ${ }^{129}$ The federal regulators have argued that the heavy presence of federal regulation in banking requires the courts to acknowledge a federal common law. ${ }^{130}$

Even in the case of federally chartered depository institutions, fiduciary duties traditionally have been regarded as creations of, and governed by, state law. Under the two-part approach articulated by the Supreme Court in United States v. Kimbell Foods, Inc., ${ }^{131}$ it is necessary to demonstrate not only that Congress intended federal law to govern the agency, but also that the federal courts should, as a matter of policy, fashion a uniform priority rule that would displace applicable state law. Reaching a decision on the policy issue involves a consideration of three factors: whether the federal program involved must be

desire to prevent institutional failure, to encourage the gamble itself. The incentive is especially strong when the SAIF reaches the point where failure of the institution would require the OTS to request more appropriations from Congress (thereby subjecting itself to further excoriation in Congress). What is the institutional management's fiduciary duty now?

126. One should bear in mind that this general duty would be separate and distinct from those fiduciary duties already owed under state law by officers and directors to their institutions.

127. The FDIC has also been trying to establish a federal common law of depositor priority, which would override state law provisions to the contrary. Its attempt to secure congressional assistance has, thus far, failed, and its fortunes in the courts have been mixed. See Samantha Evans, Note, An FDIC Priority of Claims Over Depository Institution Shareholders, 41 DUKe L.J. 329 (1991); Alan J. Cooke, Shareholders' Rights of Recovery When Banks Fail: Why the FDIC Should Not Receive Priority, 11 ANN. REV. BANKING L. 449 (1992).

128. See OTS Issues C\&D Order Against Neil Bush for Engaging in Conflicts of Interest, 56 BNA BANKING REP. 761, 762 (1991).

129. Id. (reporting on an Interpretive Letter dated Aug. 8, 1990, in which the OCC Chief Counsel asserted that federal law governs fiduciary practices at national banks). See OCC Can Narrow, Deny Outer Limits of State-Granted Fiduciary Powers, 55 BNA BANKING REP. 991, 991 (1990).

130. See, e.g., Arthur W. Leibold, Jr., Federal Common Law: What and Where?, in PRACTISING LAW INSTITUTE, CIVIL AND CRIMINAL LIABILITY OF OFFICERS, DiReCTORS, AND PROFESSIONALS: BANK \& THRIFT LITIGATION IN THE 90s, at 153 (1991). (See also the longer, unpublished version of this article, on file with the author.)

131. 440 U.S. 715 (1979). 
uniform in character; whether application of state law would frustrate the specific objectives of the program; and whether the application of a uniform federal law would disrupt commercial relationships predicated on state law. ${ }^{132}$ So far, the proponents of the general fiduciary duty have made no attempt to provide arguments as to the applicability of these three factors beyond the bald assertion that important federal interests are at stake. On the other hand, an argument for recognition of a federal common law governing the fiduciary duties of bank officers, directors, and outside parties, which was recently made by private litigants, was rejected after full briefing ${ }^{133}$ and in a fully reasoned opinion in a case involving a federally chartered savings bank. ${ }^{134}$

The recognition of a general fiduciary duty owed to the regulators might, therefore, offer practical advantages to the regulators. But the arguments supporting the duty are inconsistent with the existing statutory structure. Nor has a thorough argument yet been made as to why the courts should supplement the agencies' statutory powers with the right to invoke a general fiduciary duty based on federal common law. This would constitute a new delegation of power, which should at least require congressional action. Congress, after all, has not shown itself unwilling to provide the regulators with additional enforcement powers when such powers are requested. ${ }^{135}$

\section{ATTORNEYS AS "INSTITUTION-AFFILIATED PARTIES"}

Any discussion of the fiduciary duty issue in the banking context would be incomplete without addressing some of the anxieties the controversy has generated within the legal profession. In the wake of the calamity of the Great Depression, Chief Justice Stone was moved to admonish the Bar for failing to "attain its accustomed place of recognized leadership." 136 The nation, the Chief Justice continued, could not rely on "the policeman" and his "nightstick" alone. $^{137}$ It was entitled to expect lawyers to discharge a responsibility that went beyond merely protecting the rights of their clients and facilitating corrupt practices by corporate officers and directors through the provision of "clever legal devices." 138 He predicted that "when the history of the financial era which ha[d] just drawn to a close comes to be written, most of its mistakes and its major faults will be ascribed to the failure to observe the fiduciary principle,

132. Id. at 728-29. For a thorough analysis of the application of this three-factor test in the context of depositor priority disputes, see Evans, supra note 127, at 345-59.

133. See Amerifirst's Memorandum of Law in Opposition to Defendant's Motions to Dismiss the Amended Complaint at 32-56, Amerifirst Bank v. Bomar, 757 F. Supp. 1365 (S.D. Fla. 1991) (No. 900429-Civ-Hoeveler).

134. Amerifirst Bank v. Bomar, 757 F. Supp. 1365, 1372-74 (S.D. Fla. 1991).

135. See supra note 95.

136. Harlan F. Stone, The Public Influence of the Bar, 48 HARV. L. REV. 1, 4 (1934).

137. Id.

138. Id. at 9 . 
the precept as old as holy writ, that 'a man cannot serve two masters."'139 There was "little to suggest," he added, "that the Bar has yet recognized that it must bear some burden of responsibility for these evils." 140

The tendency to blame lawyers for exploiting "loopholes" on behalf of clients in the financial services industry has an almost cyclical quality. ${ }^{141}$ Insofar as many lawyers appear to have neglected or disregarded their ethical and legal responsibilities, the blame is entirely appropriate. But the suggestion that lawyers should disregard their legitimate ethical and legal responsibilities to their clients in favor of a general duty to play public watchdog seems more the product of regulatory zealotry and public hysteria than reasoned analysis.

The concern this time over the role of lawyers was triggered by dicta of Judge Stanley Sporkin in his decision involving the notorious Lincoln Savings \& Loan Association. ${ }^{142}$ Judge Sporkin found considerable evidence to support the conclusion of the regulators that Charles Keating's American Continental Corporation had systematically looted its subsidiary, Lincoln Savings \& Loan Association. After upholding the seizure of Lincoln by those regulators, Judge Sporkin added a special postscript to his opinion, in which he posed a number of questions:

Keating testified that he was so bent on doing the "right thing" that he surrounded himself with literally scores of accountants and lawyers to make sure all the transactions were legal. The questions that must be asked are:

Where were these professionals, a number of whom are now asserting their rights under the Fifth Amendment, when these clearly improper transactions were being consumated?

Why didn't any of them speak up or disassociate themselves from the transactions?

Where also were the outside accountants and attorneys when these transactions were effectuated? ${ }^{143}$

"Here it is clear," Judge Sporkin concluded, "[that] the private sector was not willing to cooperate with the public oversight regulators." 144

These remarks triggered a round of debates, during which Mr. Weinstein and other government officials were able to elaborate further on the fiduciary duty doctrine as it relates to institution-affiliated parties such as outside counsel. ${ }^{145}$

139. Id. at 8 .

140. Id. at 9 .

141. See, e.g., Dennis J. Lehr, Balancing the Fourth Branch: Dealing With FDIC/RTC Focus on Attorney Conduct, 57 BNA BANKING REP. 59, 61 (1991). ("In the area of financial institution regulation, the word 'loophole' has been around for many years."). Mr. Lehr also reminds us of the efforts by the regulators to impose client-policing duties on the securities bar during the early $1970 \mathrm{~s}$. Id. at 62 . One is also reminded of the "tax loophole lawyers" rhetoric that was so prevalent during the early 1980s.

142. Lincoln Savings \& Loan Ass'n v. Wall, 743 F. Supp. 901 (D.D.C. 1990).

143. Id. at 919-20.

144. Id. at 920 .

145. See, e.g., Attorney Malpractice, supra note 43, at 545-46; Advice on How to Exploit Loopholes May Be Unethical, OTS' Weinstein Says, 56 BNA BANKING REP. 616 (1991) (reporting on panel discussion sponsored by the Administrative Conference of the United States entitled "Where Were the Lawyers?," Washington, D.C., Mar. 21, 1991) [hereinafter How to Exploit Loopholes]; Draft Bills, supra note 43, at 766-67 (reporting on proceedings of Spring Meeting of ABA Section of Business Law); Keith R. Fisher, Regulators Find New Deep Pockets in Bank Counsel, 4 BANKING L. REV. 3 (Summer 1991); 
The debates also provoked some strong reactions. The American Bar Association responded immediately by establishing a Task Force on the Liability of Counsel Representing Depository Institutions. ${ }^{146}$ Other responses took the form of the introduction in the Ohio State Senate, ${ }^{147}$ and the actual passage in the Louisiana and Texas state legislatures, ${ }^{148}$ of various forms of legislation limiting (in the case of Louisiana) the liability of attorneys and accountants to "traditional concepts of legal or accounting malpractice," 149 and providing for damages and the costs of defense against anyone attempting unsuccessfully to impose greater standards of responsibility or liability. ${ }^{150}$ The Kaye Scholer incident $^{151}$ added yet new impetus to the controversy. ${ }^{152}$

As far as outside counsel are concerned, ${ }^{153}$ however, the exact scope of enforcement liability implications of the broad fiduciary doctrine is not always easy to discern. The enforcement legislation itself provides that an attorney who "knowingly, or recklessly participates in" a breach of this general fiduciary duty will, if the breach has "caused or is likely to cause more than a minimal financial loss to, or a significant adverse effect on, the insured depository institution,"154 be subject to enforcement action. The outer boundaries of this accomplice-type

Lehr, supra note 141, at 59-60; John K. Villa, Accountants, Lawyers Face Enforcement Threat, AM. BANKER 4, Apr. 10, 1991.

For a masterly theoretical analysis of the broader disciplinary issues invoked by this demand for greater professional accountability, see David B. Wilkins, Who Should Regulate Lawyers?, 105 HARV. L. REV. 799 (1992).

146. See ABA Task Force Studies Liability of Counsel for Depository Institutions, 55 BNA BANKING REP. 755, 755 (1990).

147. S. 136, introduced Apr. 18, 1991. See Draft Bills, supra note 43, at 766.

148. 1991 La. Sess. Law Serv. 602 (West); 1991 Tex. Sess. Law Serv. 901 (Vernon) $\$ 84$ (restricting the liability of partners in a limited liability partnership with respect to debts and obligations of the partnership). The Texas legislation, though general in application, was also inspired by the threat of regulatory action by the federal banking regulators against attorneys. See Christie Harlan, Texas and

Louisiana Move to Shield Personal Assets of Law Firm Partners, WALl ST. J., Mar. 13, 1992, at A6.

149. 1991 La. Sess. Law Serv. 602 (West) § 1352.

150. Id. \& 1354.

151. See supra text accompanying note 5 .

152. See, e.g., Rita H. Jensen, Kaye Scholer's Lincoln Woes, NAT'L L.J. Mar 16, 1992, at 1; David Margolick, Lawyers Under Fire, N.Y. Times, Mar. 10, 1992, at A1; Amy Stevens \& Paulette Thomas, Legal Crisis: How a Big Law Firm Was Brought to Knees by Zealous Regulators, WALL ST. J., Mar. 13, 1992, at A1; American Professions: On the Defensive, ECONOMIST, Mar. 14-20, 1992, at 90, 92 . In response to the Kaye Scholer affair, the President of the American Bar Association appointed a large Working Group on Lawyers' Representation of Regulated Clients. The New York City Bar Association also issued a report urging restrictions on the use of the agencies' asset-freeze powers. See Bar Association Spars, WALl ST. J., Apr. 1, 1992, at B6.

It should be noted that the OTS went to some lengths to emphasize the special facts of the Kaye Scholer case, and to disavow any reliance upon new legal theories in the notice of charges that initiated the enforcement action and supported the imposition of the asset freeze; Harris Weinstein, Remarks Delivered at Pennsylvania Association of Community Bankers 1-2, 9 (Mar. 23, 1992) (transcript on file with author) [hereinafter Pennsylvania Address]; Weinstein Defends Enforcement Action, Asset Order Against Kaye Scholer Firm, 58 BNA BANKING REP. 610 (1992) (reporting on remarks by Chief Counsel Weinstein on a panel at a Prentice Hall Law \& Business Conference, Washington, D.C. Mar. 30, 1992) [hereinafter Washington Panel].

153. There seems to be general agreement that attorneys who act as directors should be subject to the same principles of liability as other, non-attorney directors.

154. 12 U.S.C. \& 1813(u)(4). 
liability remain far from clear, turning as they do on the construction of such complicated concepts as "participate," "knowingly," and "recklessly."

It does seem crystal clear that Congress took into account many of the concerns expressed to it vociferously by the bar when crafting the new enforcement powers, ${ }^{156}$ and that no significant new forms of liability were envisaged. In a report that was otherwise concerned with emphasizing the importance of vigorous enforcement action, the House Banking Committee went out of its way to provide reassurance that no fundamental change in professional responsibility was envisaged: By specifying "attorney" in [the section creating the "institution-affiliated party"
concept], the Committee does not intend to subject attorneys to agency
enforcement actions for those good faith activities falling within the traditional
attorney-client relationship. Specifically, providing advice in good faith to a
client financial institution, by itself, should not lead to an enforcement action.
For example, an attorney who provides legal advice or other legal services in
good faith to a financial institution may counsel the institution that a particular
course of action is lawfully justifiable, because of unclear law or regulations or
because the institution may succeed on a legal challenge to the law or regulation
during an administrative or judicial proceeding. That such advice or services
may conflict with the position of the Federal banking agency and that a court
may determine that position to be wrong would not usually or necessarily show
bad faith. Also, the legal advice provided under these circumstances would
probably not be considered "counselling" a violation of law, one of the
definitions of "participation" specifically cited in section $8(i)$ of the Federal
Deposit Insurance Act, amended by [the section providing for (enhanced) civil
money penalties]. (Such advice, however, will not shield the client from civil
enforcement action and would only be relevant as a mitigating factor in a civil
money penalty action.)
Thus, under most circumstances, such advice would not constitute a
participation in the conduct of the affairs of the institution. However, an
attorney who does provide legal advice and services and then knowingly
participates in other activities which result in serious misconduct would be
subject to enforcement actions. Moreover, repeated legal advice to violate a
banking law provision in title 12 , U.S. Code, where the meaning of the provision
is clearly established or settled by the courts, would not usually constitute good
faith, and could possibly subject the attorney involved to enforcement action, if
the grounds for such action are present (and conceivably could give rise to State
bar disciplinary proceedings). ${ }^{15}$.

155. As Mr. Lehr observes, each of these terms have been the subject of prior judicial interpretation and are likely to be subject to protracted judicial analysis in the enforcement context. Lehr, supra note 141 , at 60.

156. Members of the banking industry and the bar protested the severity of the proposed new enforcement powers. See, e.g., Prosecuting Fraud in the Thrift Industry: Hearings on H.R. 1278 Before the Subcomm. on Criminal Justice of the House Judiciary Comm., 101st Cong., 1st Sess. 1, 79, 271 (1989) (statements of John Villa, banking attorney, and Edward Yingling for the American Bankers Association). See also FHLBB, Justice Dept. Lawyers Outline S\&L Bill Criminal Provisions at D.C. Meeting, 52 BNA BANKING REP. 1150, 1150-51 (1989); Fisher, supra note 145, at 5-6; Lehr, supra note 141 , at 59-60 (referring to representations to the House and Senate Banking Committees made on behalf of the American Bar Association).

157. REPORT OF THE HOUSE COMMITTEE ON BANKING, FINANCE AND URBAN AFFAIRS, FinANCIAL INSTITUTIONS REFORM, RECOVERY AND ENFORCEMENT ACT OF 1989, H.R. REP. NO. 54(I), 101st Cong., 1st Sess. 467 (1989), reprinted in 1989 U.S.C.C.A.N. 86, 263. 
Despite this reassuring language, the regulators seem intent on adding a further gloss to the legislative history that would tend to enhance their prospects of success in their civil and agency enforcement actions against attorneys and other professionals. In seeking to extend the net of attorney liability, the regulators have followed two tacks: first, Mr. Thomas of the FDIC has suggested that because the FDIC would become the receiver of an insured depository institution if it were seized by the regulators, the FDIC is as much the "client" of counsel as the institution itself. This, he argues, implies that the FDIC, as the "client," can waive the attorney-client privilege upon which counsel rely for refusing to disclose confidential client information to the regulators. ${ }^{158}$

Adopting a more direct approach, Mr. Weinstein of the OTS asserts that attorneys have an enforceable, ethical duty to practice what he terms "whole law." Thus, an attorney advising or acting on behalf of an insured depository institution must determine "his or her true obligations by reference to regulatory requirements, concepts of safety and soundness, and fiduciary responsibilities."159 Such attorneys are under a duty to make further inquiries, when presented by their client institutions with information suggesting that related legal questions are involved, as to whether proper legal advice with respect to those questions has been obtained. The OTS, Mr. Weinstein noted, was considering giving practical effect to these views by expressly requiring, in informal supervisory agreements, expanded disclosure by counsel advising institutions under supervision on flagged matters: attorneys who see such "red flags" are liable to enforcement action should they ignore them. ${ }^{160}$ There are even some indications that the regulators, apparently assuming the existence of a direct fiduciary relationship between attorneys and themselves, ${ }^{161}$ contemplate

158. See Attorney Malpractice, supra note 43, at 546 (reporting on Mr. Thomas's views). Even though more limited than Mr. Weinstein's, Mr. Thomas's view is still problematic. Mr. Thomas might be understood to mean no more than that because the FDIC is the successor in interest to failed institutions, it can seek damages for breaches of duties owed to those institutions by their attorneys. But his remarks were couched in a tone that suggested new (or previously unenforceable) liability for attorneys, and the full implications intended by his remarks are difficult to discern. For example, can the fiduciary duty to the regulator only be established retrospectively, once the institution has been seized? Or does it apply in the case of all insured institutions because the regulator is always a potential "client"? If the latter is the correct answer, this would effectively obliterate any notion of confidentiality between attorney and institutional client, at least as far as the regulator is concerned. For a more thorough analysis of the "client" question, see H. Brent Helms, Comment, Financial Institutions Reform, Recovery and Enforcement Act: An Ethical Quagmire for Attorneys Representing Financial Institutions, 27 WAKE FOREST L. REV. 277, 306-11 (1992).

159. See How to Exploit Loopholes, supra, note 145, at 616.

160. Id. at 617 . Disclosure might also include having to inform the regulators if counsel were to resign. Id. See Thrift Lawyers Can be Regulated by OTS, Senior Official Says, 56 BNA BANKING REP. 1202, 1203 (1991) [hereinafter Thrift Lawyers] (interview with OTS Deputy Chief Counsel, indicating that the Weinstein proposals have already been implemented in the case of consent agreements).

161. In the realm of federal securities law, the Supreme Court has insisted that a duty to disclose arises from the relationship between the parties and will exist only where there is "a fiduciary or other similar relation of trust and confidence between them." Chiarella v. United States, 445 U.S. 222, 228 (1980) (quoting RESTATEMENT (SECOND) OF TORTS § 551(2)(a) (1976)). See also Schatz v. Rosenberg, 943 F.2d 485, 490 (4th Cir. 1991) (finding no duty to diclose where attorneys and plaintiff were not in "some fiduciary or other confidential relationship"). 
that this responsibility of disclosure extends as far as requiring attorneys, even in the absence of such supervisory agreements, to seek advice from the regulators or even gratuitously to inform regulators of the transactions in which they are engaged where they have reason to suspect that the regulators might have an interest. ${ }^{162}$ "Whole law," as a "comprehensive view of technical regulatory standards," rests on "the principle that imposes hostility to law-avoidance schemes." 163

These assertions seem to reflect an effort to impose what Professor Kraakman has described as "gatekeeper liability."164 The banking regulators have been placed under intense pressure from Congress, the White House, and the media, in a steady barrage of criticism relating to their supposed inattentiveness during the freewheeling years of the mid- to late-1980s. The impression has been created, rightly or wrongly, that many of the problems relating to the banking and thrift industries can be avoided by more rigorous regulation, and much recent political action has been directed toward shifting the focus onto the regulators as "part of the problem." 165 Under these circumstances, and faced with an almost gargantuan task of trying to beat the odds in an environment of inevitable "regulatory lag," 166 the regulators seem (perhaps understandably, given the political constraints within which they must function) to be inclined to want to enlist the assistance of professionals, including outside counsel, in their efforts to prevent, or at least apprehend, abusive and deleterious behavior by insiders. ${ }^{167}$

In his valuable analysis of strategies for targeting liability for harmful corporate conduct, Professor Kraakman has identified three types of obstacles

162. See Fisher, supra note 145, at 4 n.5 (citing FDIC v. Eckert Seamans Cherin \& Mellott, No. 900488 (E.D.N.Y., complaint filed 2/8/90) involving "scattered allegations of failure by national bank's outside counsel to advise Comptroller about certain transactions"). See also Byrd \& Sammons, supra note 74, at 425-31; FDIC Seeks \$300 million in Suit Against Law Firm; Alleges Malpractice, Negligence, 54 BNA BANKING REP. 547 (1990) (reporting the filing of the FDIC complaint).

163. How to Exploit Loopholes, supra note 145, at 617. Mr. Weinstein argues that this principle can be traced to Gregory v. Helvering, 293 U.S. 465 (1935), in which the Court indicated that a corporate reorganization plan that would have the effect of avoiding taxes must have a legitimate business purpose if it is not to be regarded as a sham transaction and, hence, an evasion of the Revenue Code. But it does not necessarily follow from this proposition that an otherwise lawful transaction can only escape being label "law-avoiding" if it also comports with the views and policies of the regulators as to what constitutes prudent banking. See Lehr, supra note 141, at 60-61.

164. Reiner H. Kraakman, Corporate Liability Strategies and the Costs of Legal Controls, 93 YALE L.J. 857, 888 (1984).

165. Recent events such as the BCCI scandal and the New England credit crunch have all generated congressional criticism of the regulators. One of the most prominent symbolic acts was the refusal, by the US Senate Committee on Banking, Housing and Urban Affairs, to refer to the full Senate the nomination by the President of Robert Clarke for a second term as Comptroller of the Currency. See, e.g., Senate Banking Committee Votes 12-9 to Reject Clarke for Second OCC Term, 57 BNA BANKING REP. 758 (1991).

166. "Regulatory lag" refers to the fact that banking examinations are inevitably conducted "after the fact" of unsafe and unsound conduct and, because of the infrequency of such examinations, it is often too late to correct the situation or to take meaningful enforcement action to prevent further deterioration in the institution's condition.

167. For further thoughts in this regard, see Baxter, supra note 16, at S237-38. 
that might provide, as a policy matter, the occasion for imposing extended liability on corporate insiders and influential outsiders, including attorneys (or, in the banking context, institution-affiliated parties). He terms these obstacles ones of "asset insufficiency," "sanction insufficiency," and "enforcement insufficiency." 168 All three are clearly relevant to the problems of banking enforcement. ${ }^{169}$

Asset insufficiency occurs, in its simplest form, where the assets of the institution itself are insufficient to cover the losses caused by the institution's misfeasance. ${ }^{170}$ In the case of a failed depository institution, this is true by definition. In such circumstances, the attraction of imposing personal liability on individuals associated with the institution is obvious. ${ }^{171}$ The history of congressional enforcement enhancement since 1966, and particularly in $1989,{ }^{172}$ provides a tailor-made illustration of the response predicted by Professor Kraakman to the problems of sanction insufficiency facing the regulators. So, too, was the explicit extension of liability to outsiders. The creation of the "institution-affiliated party" concept by Congress in its 1989 FIRREA legislation $^{173}$ is a direct response to the problem of enforcement insufficiency. It is a recognition of the fact that the regulatory system depends heavily on proper, lawful conduct by outside "gatekeepers," who are in the unique position of being able to prevent unlawful conduct by their principals. ${ }^{174}$

\section{VI \\ CONCLUSION}

This is the context in which Mr. Weinstein's exhortations to the practice of "whole law" should be understood. While it is true that his views, if taken literally, would assert novel grounds of liability for outside counsel, close analysis of his statements suggest that they contain a good deal more hortatory language than serious claims to new liability. Nor could it be otherwise. The legislative history underlying the enactment of the "institution-affiliated party" provision

168. See Kraakman, supra note 164 , at $867-68$.

169. A thorough analysis of the efficiency of enforcement policy would of course need to take into account a number of variables. See, e.g., Christopher D. Stone, Choice of Target and Other Law Enforcement Variables in SANCTIONS AND REWARDS IN THE LEGAL SYSTEM 203 (Martin L. Friedland ed., 1989).

170. See Kraakman, supra note 164 , at 869 .

171. Imposing absolute liability on "deep pockets," such as insurance companies, also has obvious benefits as a means of remedying asset insufficiency.

172. See supra text accompanying notes $28-32$.

173. See supra text accompanying notes 31-32.

174. See, e.g., Weinstein Speech, supra note 43, at 510 ("Our system heavily depends on the self regulation of principled business executives, whose counsel understand and execute their professional duties to provide sound advice and who decline to represent clients whose objective is evasion rather than voluntary fulfillment of their fiduciary obligations."). See also Marianne Lavelle, How OTS Set the Stage for Order Against Firm, NAT'L LJ. Mar. 16, 1992, at 32 ("Many observers see the \$257 million administrative action against New York's Kaye, Scholer, Fierman, Hays and Handler as an astute use of limited resources by OTS, an agency with only about 140 in-house lawyers that does not hire outside counsel."). 
expressly abjures any change in the substantive law relating to attorney liability, ${ }^{175}$ and one would expect a clearer statement from Congress had it intended such a change. This is particularly so when one considers the complicated consequences that would flow from such a change. In the first place, it might well involve a substantial modification to ethical ${ }^{176}$ and professional liability standards (governed hitherto mainly by state law), and, insofar as disclosure duties might be involved, ${ }^{177}$ a fundamental departure from our adversary system of advocacy. ${ }^{178}$ Secondly, such a change would inevitably lead to a reallocation of resources and supervisory responsibilities: Gatekeeper liability, involving an extensive duty of "due diligence," $"$ would not be without its costs. ${ }^{180}$ It could well create a counterproductive, chilling effect on the quality of legal advice and decision making. ${ }^{181}$ It could also entail increased professional liability insurance premiums ${ }^{182}$ and much more expensive legal advice (the legal equivalent of "defensive medicine"), the cost of which would

175. See supra text accompanying note 157 .

176. The ethical principles most obviously implicated are the duties of confidentiality (MODEL RULES of Professional CONDUCT Rule $1.6(1989)$ ) and loyalty to one's client (MODEL RULES OF Professional Conduct Rule 1.7 (1989)). For an analysis of the ethical issues involved, see Helms, supra note 158, at 291-306.

177. Although Mr. Weinstein has been at pains to disavow any intention to impose "whistleblower" duties on attorneys, see Pennsylvania Address, supra note 152, at 9, his assertion that withdrawal from representation alone might be insufficient for avoiding liability, and that positive disaffirming action on the part of an attorney could be required, see Washington Panel, supra note 152, at 612, inevitably raises thorny questions regarding the obligation to disclose to the regulators otherwise confidential client information.

178. For some views on the dubious desirability of departing from the traditional principles of zealous and loyal advocacy by lawyers for their clients, and the implications of imposing "whistleblower duties" on attorneys, see, e.g., Helms, supra note 158, at 283-87; Lehr, supra note 141, at 61-63; and the views reported by Margolick, supra note 152 .

179. See How to Exploit Loopholes, supra note 145, at 618 (reporting Mr. Sidney Rosdeitcher's description of the implications of the "whole law" theory).

180. See, e.g., Lehr, supra note 141, at 62-63 (describing some of the options-either more expensive or simply abdicative-attorneys are likely to pursue under threat of extended liability); How to Exploit Loopholes, supra note 145, at 618 (reporting Professor Wolfram as predicting that "[w]e're going to require lawyers to do a great many more things, and lawyers aren't going to do it for free. The clients are going to have to pay for it.").

Leaving aside the special difficulties associated with imposing gatekeeper liability on attorneys, such liability is likely, in any event, to be a mixed blessing: "th[e] extensive reach of gatekeeper liability ... suggests that it generally acts to magnify both the costs of compliance for innocent parties and the benefits of effective deterrence for guilty ones in comparison with liability imposed on controlling managers." Kraakman, supra note 164 , at 891.

181. See, e.g., Baxter, supra note 16, at S238. Lawyers are familiar with the forbidding effect of the prospect of "fraud by hindsight" liability that can arise in litigation arising out of decisions that turned out to be misjudgments. See, e.g., Lewis A. Kaplan \& Roberto C. Quinones, Defending Against "Fraud by Hindsight" Cases, AM. BANker, Mar. 31, 1992, at 4. Cf. Peter P. Swire, Bank Insolvency Law Now That It Matters Again, 42 DUKE L.J. 469, 553 (1992) (discussing the possible "black hole effect" of early intervention powers, under which institutions that might otherwise survive could be plunged into insolvency by the sheer weight of regulatory action).

182. For early indications, see Ellen J. Pollock \& Christi Harlan, Law Firm Insurance Premiums May Rise, WALl ST. J., Apr. 1, 1992, at B6 (reporting that premium increases of as much as $50 \%$ over the next two years are anticipated by some insurance executives as a result of the Kaye Scholer settlement and settlement of another Lincoln S\&L-related lawsuit involving the law firm of Jones, Day, Reavis \& Pogue). 
ultimately be passed on to consumers of banking services. ${ }^{183}$ And the imposition of a fiduciary duty owed directly to the regulators would create an incentive for attorneys to err on the side of caution to avoid becoming ensnared in the regulatory enforcement net. ${ }^{184}$ Such a rearrangement of the regulatory regime, even if desirable, should be based upon a more thorough, complex, and delicate balance of judgment than may be within the capacity of the banking regulators acting on their own. ${ }^{185}$

It is, in a nutshell, a very open question as to whether, even if it were to attract express congressional sanction, the sweeping imposition of gatekeeper liability in the form apparently envisaged by the regulators would truly be worth it. ${ }^{186}$ Until this judgment has been carefully made, we should not force the overworked fiduciary doctrine to bear more than its fair share of responsibility for the viability of the nation's banking industry.

183. The likelihood of expensive, prophylactic legal costs is especially great given the fact that bank safety and soundness involves such speculative, business judgment, see supra text accompanying note 100 , and that the "whole law" approach inevitably leads to the imposition of a "should-have-known" standard of liability on attorneys. See How to Exploit Loopholes, supra note 145, at 618 (quoting Mr. Rosdeitcher).

184. This danger is particularly real because regulators are fully aware of the "deep pocket" and vulnerable nature of law-firm defendants. See, e.g., Fisher, supra note 145, at 3, 12.

185. See Wilkins, supra note 145 , passim (analyzing the numerous competing considerations involved in the various lawyer-discipline strategies actually or potentially available).

186. If traditional principles of lawyer liability are insufficient, there are still other avenues less drastic than imposing whistle-blowing duties on attorneys. For example, the Securities and Exchange Commission imposes effective agency securities-practice disbarment on attorneys who lack the requisite character or integrity, or who have engaged in unethical or unprofessional conduct. 17 C.F.R. \& 201.2(e) (1992) ("Rule 2(e) proceedings"). See, e.g., Ralph C. Ferrara, Thomas A. Ferrigno \& David S. Darland, Hardball! The SEC's New Arsenal of Enforcement Weapons, 47 BUS. LAw. 33, 91-93 (1991). Civil money penalties are not permitted. See id. at 93 . The federal banking agencies each have their own set of disciplinary rules governing counsel who practice before them. See 12 C.F.R. $\S 19$ (1992) (OCC); 12 C.F.R. \$ 263, $90-99$ (1992) (Federal Reserve System); 12 C.F.R. \$ 308, 108-09 (1992) (FDIC); 12 C.F.R. $\$ 513$ (1992) (OTS). Cf. Thrift Lawyers, supra note 160, at 1203 (reporting OTS' intention to use agency bar discipline as a means of regulating attorneys practicing in the thrift area). 


\section{STATUTORY APPENDIX \\ EXTRACTS FROM THE FEDERAL DEPOSIT INSURANCE ACT}

SEC. 3. 12 U.S.C. $§ 1813$ (Supp. II 1990)

(q) Appropriate Federal Banking Agency.

-The term "appropriate Federal banking agency" means-

(1) the Comptroller of the Currency, in the case of any national banking association, any District bank, or any Federal branch or agency of a foreign bank;

(2) the Board of Governors of the Federal Reserve System, in the case of-

(A) any State member insured bank (except a District bank),

(B) any branch or agency of a foreign bank ....,

(C) any foreign bank which does not operate an insured branch,

(D) any agency or commercial lending company other than a Federal agency,

(E) supervisory or regulatory proceedings arising from ... section 7(c)(1) of the International Banking Act of 1978 ...,

(F) any bank holding company and any subsidiary of a bank holding company (other than a bank);

(3) the Federal Deposit Insurance Corporation in the case of a State nonmember insured bank (except a District bank), or a foreign bank having an insured branch; and

(4) the Director of the Office of Thrift Supervision in the case of any savings association or any savings and loan holding company.

Under the rule set forth in this subsection, more than one agency may be an appropriate Federal banking agency with respect to any given institution.

(u) Institution-Affiliated Party.

-The term "institution-affiliated party" means-

(1) any director, officer, employee, or controlling stockholder (other than a bank holding company) of, or agent for, an insured depository institution;

(2) any other person who has filed or is required to file a change-in-control notice with the appropriate Federal banking agency ... ;

(3) any shareholder (other than a bank holding company), consultant, joint venture partner, and any other person as determined by the appropriate Federal banking agency (by regulation or case-by-case) who participates in the conduct of the affairs of an insured depository institution; and

(4) any independent contractor (including any attorney, appraiser, or accountant) who knowingly or recklessly participates in-

(A) any violation of any law or regulation;

(B) any breach of fiduciary duty; or

(C) any unsafe or unsound practice,

which caused or is likely to cause more than a minimal financial loss to, or a significant adverse effect on, the insured depository institution. 
SEC. 812 U.S.C. $\S 1818$ (Supp. II 1990)

(b) Cease-and-desist proceedings

(1) If, in the opinion of the appropriate Federal banking agency, any insured depository institution, depository institution which has insured deposits, or any institution-affiliated party is engaging or has engaged, or the agency has reasonable cause to believe that the depository institution or any institutionaffiliated party is about to engage, in an unsafe or unsound practice in conducting the business of such depository institution, or is violating or has violated, or ... is about to violate, a law, rule, or regulation, or any condition imposed in writing by the agency ... or any written agreement entered into with the agency, the agency may [initiate a formal administrative adjudication] ... to determine whether an order to cease and desist therefrom should issue against the depository institution or the institution-affiliated party. ... [After the hearing, or if the institution or party consents,] . . the agency may issue and serve upon the depository institution or institutionaffiliated party an order to cease and desist from any such violation or practice. Such order may, by provisions which may be mandatory or otherwise, require the depository institution or its institution-affiliated parties to cease and desist from the same, and, further, to take affirmative action to correct the conditions resulting from any such violation or practice.

$* * *$

(6) Affirmative action to correct conditions resulting from violations or practices.

- The authority to issue [a temporary or permanent cease and desist order] ... which requires an insured depository institution or any institutionaffiliated party to take affirmative action to correct or remedy any conditions resulting from any violation or practice with respect to which such order is issued includes the authority to require such depository institution or such party to-

(A) make restitution or provide reimbursement, indemnification, or guarantee against loss if-

(i) such depository institution or such party was unjustly enriched in connection with such violation or practice; or

(ii) the violation or practice involved a reckless disregard for the law or any applicable regulations or prior order of the ... agency;

(B) restrict the growth of the institution;

(C) dispose of any loan or asset involved;

(D) rescind any agreements or contracts; and

(E) employ qualified officers or employees (who may be subject to approval by the ... agency at the direction of such agency); and

(F) take such other action as the banking agency determines to be appropriate.

(c) Temporary cease-and-desist orders

(1) Whenever the ... agency shall determine that the violation or threatened violation or unsafe or unsound practice or practices, specified in 
the notice or charges served upon the depository institution or any institution-affiliated party . . , or the continuation thereof, is likely to cause insolvency or significant dissipation of assets or earnings of the depository institution, or is likely to weaken the condition of the depository institution or otherwise prejudice the interests of its depositors prior to the completion of [final cease-and-desist proceedings] ... , the agency may issue a temporary order requiring the depository institution or such party to cease and desist from any such violation or practice and to take affirmative action to prevent or remedy such insolvency, dissipation, condition, or prejudice pending completion of such proceedings. Such order may include any requirement authorized under subsection (b)(6) of this section. Such order shall become effective upon service . . . unless set aside, limited, or suspended by a court in proceedings authorized by paragraph (2) ....

(2) Within ten days after the depository institution concerned or any institution-affiliated party has been served with a temporary cease-and-desist order, the depository institution or such party may apply to the United States district court ... for an injunction setting aside, limiting, or suspending the enforcement, operation, or effectiveness of such order ....

(e) Removal and prohibition authority

(1) Authority to issue order. Whenever the ... agency determines that(A) any institution-affiliated party has, directly or indirectly-

(i) violated-

(I) any law or regulation;

(II) any cease-and-desist order which has become final;

(III) any condition imposed in writing by the ... agency ... ; or

(IV) any written agreement between such depository institution and such agency;

(ii) engaged or participated in any unsafe or unsound practice in connection with any insured depository institution or business institution; or

(iii) committed or engaged in any act, omission, or practice which constitutes a breach of such party's fiduciary duty;

(B) by reason of the violation, practice, or breach ...

(i) such insured depository institution or business institution has suffered or probably will suffer financial loss or other damage;

(ii) the interests of the insured depository institution's depositors have been or could be prejudiced; or

(iii) such party has received financial gain or other benefit by reason of such violation, practice, or breach; and

(C) such violation, practice, or breach-

(i) involves personal dishonesty on the part of such party; or

(ii) demonstrates willful or continuing disregard by such party for the safety or soundness of such insured depository institution or business institution, 
the agency may [serve notice of a formal administrative adjudication indicating] the agency's intention to remove such party from office or to prohibit any further participation in the affairs of any insured depository institution.

(2) Whenever, in the opinion of the ... agency, any director or officer of an insured depository institution has committed any violation of the Depository Institution Management Interlocks Act . . . the agency may serve . . . [a similar] notice of its intention to remove him from office.

(3) Suspension order

(A) Suspension or prohibition authorized. If the ... agency serves written notice under paragraph (1) or (2), the ... agency may suspend such party from office or prohibit such party from further participation in any manner in the conduct of the affairs of the depository institution, if the agency-

(i) determines that such action is necessary for the protection of the depository institution or the interests of the depository institution's depositors; and

(ii) serves such party with written notice of the suspension order.

(B) Effective period. Any suspension order ...

(i) shall become effective upon service; . . . .

(i) Jurisdiction enforcement; civil money penalty

(2) Civil money penalty.

(A) First tier. Any insured depository institution which, and any institution-affiliated party who-

(i) violates any law or regulation;

(ii) violates any final or temporary ... [cease-and-desist order, suspension, removal or prohibition order, or record-keeping and reporting requirement];

(iii) violates any condition imposed in writing ....; or

(iv) violates any written agreement ...., shall [after a formal administrative adjudication] forfeit and pay a civil penalty of not more than $\$ 5,000$ per day for each day for which the violation continues.

(B) Second tier. Notwithstanding subparagraph (A), any insured depository institution which, and any institution-affiliated party who-

(i)

(I) commits any violation described in any clause of subparagraph (A);

(II) recklessly engages in an unsafe or unsound practice in conducting the affairs of such ... institution; or

(III) breaches any fiduciary duty;

(ii) which violation, practice, or breach-

(I) is part of a pattern of misconduct;

(II) causes or is likely to cause more than minimal loss to such depository institution; or 
(III) results in pecuniary gain or other benefit to such party, shall forfeit and pay a civil penalty of not more than $\$ 25,000$ for each day during which such violation, practice, or breach continues.

(C) Third tier. Notwithstanding subparagraphs (A) and (B), any insured depository institution which, and any institution-affiliated party who-

(i) knowingly-

(I) commits any violation described in any clause of subparagraph (A);

(II) engages in any unsafe or unsound practice in conducting the affairs of such depository institution; or

(III) breaches any fiduciary duty; and

(ii) knowingly or recklessly causes a substantial loss to such depository institution or a substantial pecuniary gain or other benefit to such party by reason of such violation, practice, or breach, shall forfeit and pay a civil penalty in an amount not to exceed ...

(D) Maximum amounts ....

(i) in the case of any person other than an insured depository institution, . . \$ $\$ 1,000,000$; and

(ii) in the case of any insured depository institution, ... the lesser of-

(I) $\$ 1,000,000$; or

(II) 1 percent of the total assets of such institution.

(4) Prejudgment Attachment.

(A) In general. In any action brought by an appropriate Federal banking agency [excluding receivership suits] ... , or in actions brought in aid of, or to enforce an order in, any administrative or other civil action for money damages, restitution, or civil money penalties brought by such agency, the court may, upon application of the agency, issue a restraining order that-

(i) prohibits any person subject to the proceeding from withdrawing, transferring, removing, dissipating, or disposing of any funds, assets or other property; and

(ii) appoints a temporary receiver to administer the restraining order.

(B) Standard. A permanent or temporary injunction or restraining order shall be granted without bond upon a prima facie showing that money damages, restitution, or civil money penalties, as sought by such agency, is appropriate. 